\title{
Synthesis and Evaluation of Polyunsaturated Fatty Acid-Phenol Conjugates as Anti-Carbonyl-Stress Lipophenols
}

\author{
Céline Crauste, ${ }^{[a]}$ Claire Vigor, ${ }^{[a]}$ Philippe Brabet, ${ }^{[b]}$ Madeleine Picq, ${ }^{[c]}$ Michel Lagarde,,${ }^{[c]}$ \\ Christian Hamel, ${ }^{[b]}$ Thierry Durand, ${ }^{[a]}$ and Joseph Vercauteren*[a]
}

\author{
Keywords: Medicinal chemistry / Drug design / Fatty acids / Lipids / Polyphenols / Carbonyl stress
}

Carbonyl and oxidative stress play a substantial role in various neurodegenerative diseases such as Alzheimer's Disease, Parkinsonism, and Age-related Macular Degeneration (AMD). In retinal pathologies, both mechanisms are involved in the transformation of all-trans-retinal $(\mathrm{A} t \mathrm{R}$, reactive aldehyde) into bis-retinoid A2E. Since an accumulation of AtR and A2E contributes to photoreceptor apoptosis, we designed and synthesized a series of $O$-alkylated resorcinol derivatives featuring enhanced anti-carbonyl-stress properties. Additionally, these phenolic structures are linked to a poly- unsaturated fatty acid such as docosahexaenoic acid (C22:6 n-3; DHA) or to a lysophosphatidylcholine-DHA conjugate, in order to specifically increase their bioavailability, and thus, to target the retina. Selective syntheses of phloroglucinolDHA, resveratrol-DHA, and phloroglucinol-DHA-PC (PC = phosphatidylcholine) conjugates using silyl protecting group strategies are presented, along with results of testing that demonstrate their ability to lower AtR toxicity in ARPE-19 cell lines.

\section{Introduction}

Reactive carbonyl species, such as sugars, $\alpha$-dicarbonyls, or metabolites derived from lipid oxidation, are involved in glycation and cross-linking reactions of nucleophiles, and thus they affect cellular viability. Aging-associated disorders like age-related macular degeneration (AMD) ${ }^{[1,2]}$ but also other neurodegenerative diseases, such as Alzheimer's Disease and Parkinsonism, ${ }^{[3]}$ result from carbonyl and oxidative stress. Therefore, the discovery of agents that are dual scavengers of carbonyl compounds and oxidative stressors (anti-COS) may lead to promising therapeutic strategies. Retinal pathologies (such as AMD) are a major public health issue in the world. Suggestive evidence gathered over a number of years has implicated the retinal pigment epithelial (RPE) product lipofuscin in the etiology of atrophic AMD and genetic macular degeneration (e.g., Stargardt disease). ${ }^{[4-6]}$ Major constituents of RPE lipofuscin are the bisretinoid conjugate A2E, its photoisomers, and oxidized metabolites (epoxides, furanoid oxides, cyclic peroxides, 4hydroxy-trans-2-nonenal, etc.). ${ }^{[7]}$ Pathological A2E biosyn-

[a] Institute of Biomolecules Max Mousseron (IBMM), UMR5247-CNRS-UM1-UM2-ENSCM, Faculty of Pharmacy, 15 av. C. Flahault 34093 Montpellier, France

E-mail: jvercauteren@univ-montp1.fr http://www.ibmm.univ-montpl.fr

[b] Institute for Neurosciences of Montpellier, INSERM U1051UM1 - UM2,

34295 Montpellier, France

[c] Université de Lyon, INSERM UMR 1060 (CarMeN), INSALyon, IMBL,

69621 Villeurbanne, France

$\square$ Supporting information for this article is available on the WWW under http://dx.doi.org/10.1002/ejoc.201402282. thesis occurs when molecules of all-trans-retinal (AtR), rather than undergoing detoxification to give retinol, accumulate and react with phosphatidylethanolamine (PE) by a dual mechanism involving a combination of carbonyl and oxidative stress (COS; Scheme 1). ${ }^{[8,9]}$ This reactive aldehyde may itself also contribute to retinal dystrophy through a direct toxic effect. ${ }^{[10,11]}$ Thus, anti-COS derivatives, capable of detoxifying the main carbonyl stressor, $\mathrm{A} t \mathrm{R}$, may reduce $\mathrm{A} 2 \mathrm{E}$ formation and slow down the pace of lipofuscin deposition.

Recent literature has addressed the ability of (poly)phenols, which are known to be potent antioxidants, ${ }^{[12,13]}$ to trap reactive toxic electrophilic carbonyl entities, showing them to be potent anti-carbonyl stressors. ${ }^{[14-16]}$ One such compound is phloroglucinol, a monomer of the phlorotannin pigments abundant in brown algae; this agent has some clinical application as a spasmolytic agent, and it can reduce oxidative-stress damage in cultured cells. ${ }^{[17,18]}$ An important role has also been attributed to phloroglucinol as a scavenger under physiological conditions of common carbonyl stressors: $\alpha, \beta$-unsaturated aldehydes [such as 4 -HNE (4-hydroxynonenal) or acrolein $]^{[19]}$ and $\alpha$-dicarbonyl compounds (methylglyoxal). ${ }^{[20]} \mathrm{A}$ major disadvantage of such a compound for the treatment of retinal disorders is its poor lipid solubility and low bioavailability.

Similarly to several other research groups working on natural polyphenols, ${ }^{[15,16,21-23]}$ our strategy to improve the lipophilicity and enhance the cell penetration, relies on two chemical modifications of the resorcinol core: etherification of the phenolic functional group(s) in order to modulate their nucleophilicity, and attachment of a lipid moiety. We 


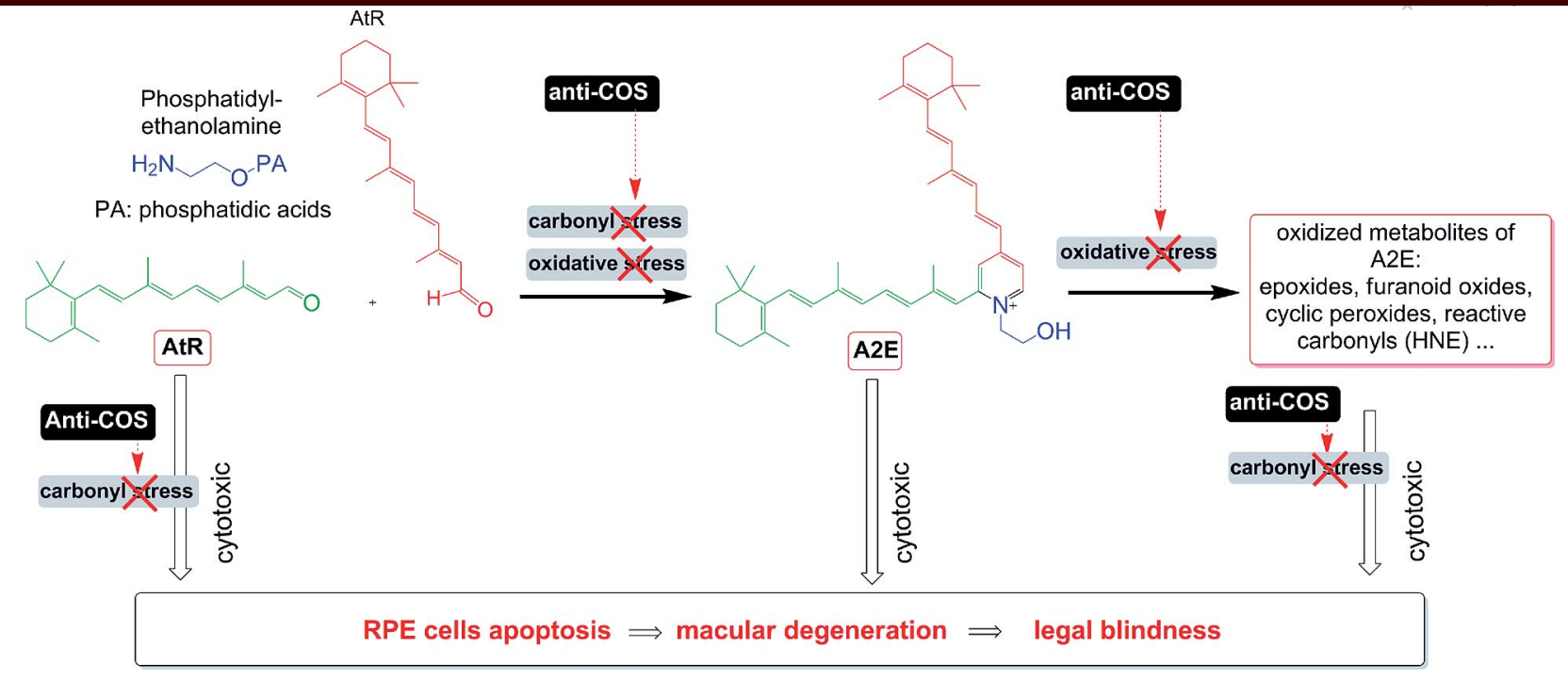

Scheme 1. How anti-COS could be active to reduce macular degeneration.

chose to use docosahexaenoic acid (C22:6 n-3, DHA) as the lipid part. This has commonly been used in the design of new conjugated drugs. ${ }^{[23-27]}$ In our case, we propose that it will improve selectivity for the retina, since the retinal content of this polyunsaturated fatty acid (PUFA) is disproportionately high. ${ }^{[28]}$

According to the results of several physiological studies, a lysophosphatidylcholine-DHA conjugate [1-lyso-2-DHAPC, glycerophosphatidylcholine, in which only one hydroxy group at the 2-position ( $s n-2)$ of the glycerol backbone is acylated by DHA] may facilitate transport of DHA to the brain or retina. ${ }^{[29,30]}$ Therefore this lysophospholipid conjugate will also be considered as a lipid vector. In this paper, we describe the first synthesis of these new lipophenols, and evaluate their ability to protect ARPE-19 cell lines from carbonyl stress. These cultured-cell experiments led to the identification of a potent derivative that can significantly increase cell survival compared to the unmodified phloroglucinol nucleus.

\section{Results and Discussion}

\section{Phloroglucinol as a Carbonyl Scavenger}

We started by checking the assumption that phloroglucinol could trap the type of carbonyl stressors involved in retinal disorders. We found that a chromene adduct $\mathbf{A}$ (Scheme 2) could be formed when phloroglucinol is treated with an equimolar amount of $\mathrm{A} t \mathrm{R}$. This $2 \mathrm{H}$-chromene $\mathbf{A}$ is clearly the result of first, a 1,2-C-addition of the free carbon

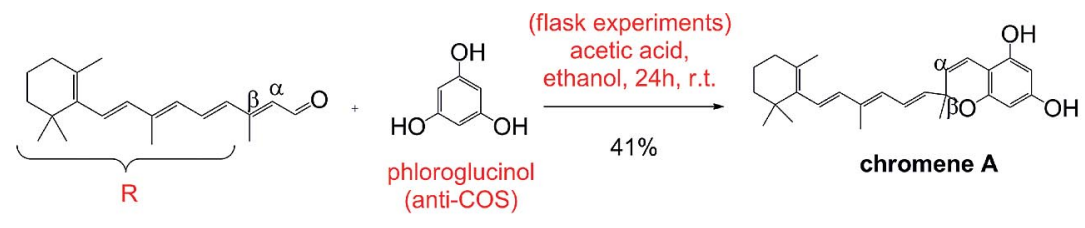

Proposed mechanism for chromene A formation:<smiles>[R]C(C)=CC(O)c1c(O)cc(O)cc1O</smiles>

Alternative chromene structures, never isolated :<smiles>CC1(C)CCOC2CC(O)CC(O)C21</smiles>

4H-chromene

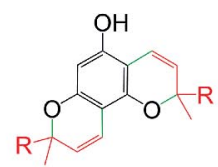

unsymmetric di-adduct

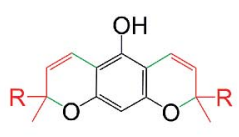

symmetric di-adduct

Scheme 2. Formation of chromene A by reaction of phloroglucinol with trans-retinal. 
atom of the resorcinol framework onto the carbonyl group of A $t \mathrm{R}$, followed by an intramolecular $O$-addition onto the double bond of the allylic benzyl alcohol. The alternative $4 H$-chromene regioisomer is not seen, probably due to the hindered $\beta$-carbon of the double bond that precludes Michael-type 1,4-addition. Furthermore, when $2 \mathrm{H}$ chromene $\mathbf{A}$ is formed, theoretically, it could react further to scavenge at least one more molecule of $\mathrm{A} t \mathrm{R}$. However, neither the symmetrical nor the unsymmetrical diadducts could be seen. Presumably, this is related to the incorporation of the polyisoprenic side-chain, which must make it too hydrophobic to remain in the ethanolic phase.

With this background information, we synthesized various polyphenol conjugates containing a resorcinol back- bone linked to DHA, to evaluate a possible protective effect against AtR-induced carbonyl stress in RPE cells.

\section{Synthesis of DHA-Phloroglucinol Conjugates}

The DHA used in the following synthesis was extracted from cod liver oil using a process developed to concentrate PUFAs starting from fish or algal oil. ${ }^{[31]}$ The process was carried out in a single step: fish liver oil was saponified in the presence of $\mathrm{NaOH}$, and free fatty acids were extracted using liquid-liquid extraction, and separated from the unsaponifiable material. Subsequently, monounsaturated fatty acids were removed by urea complexation, ${ }^{[32]}$ based on the

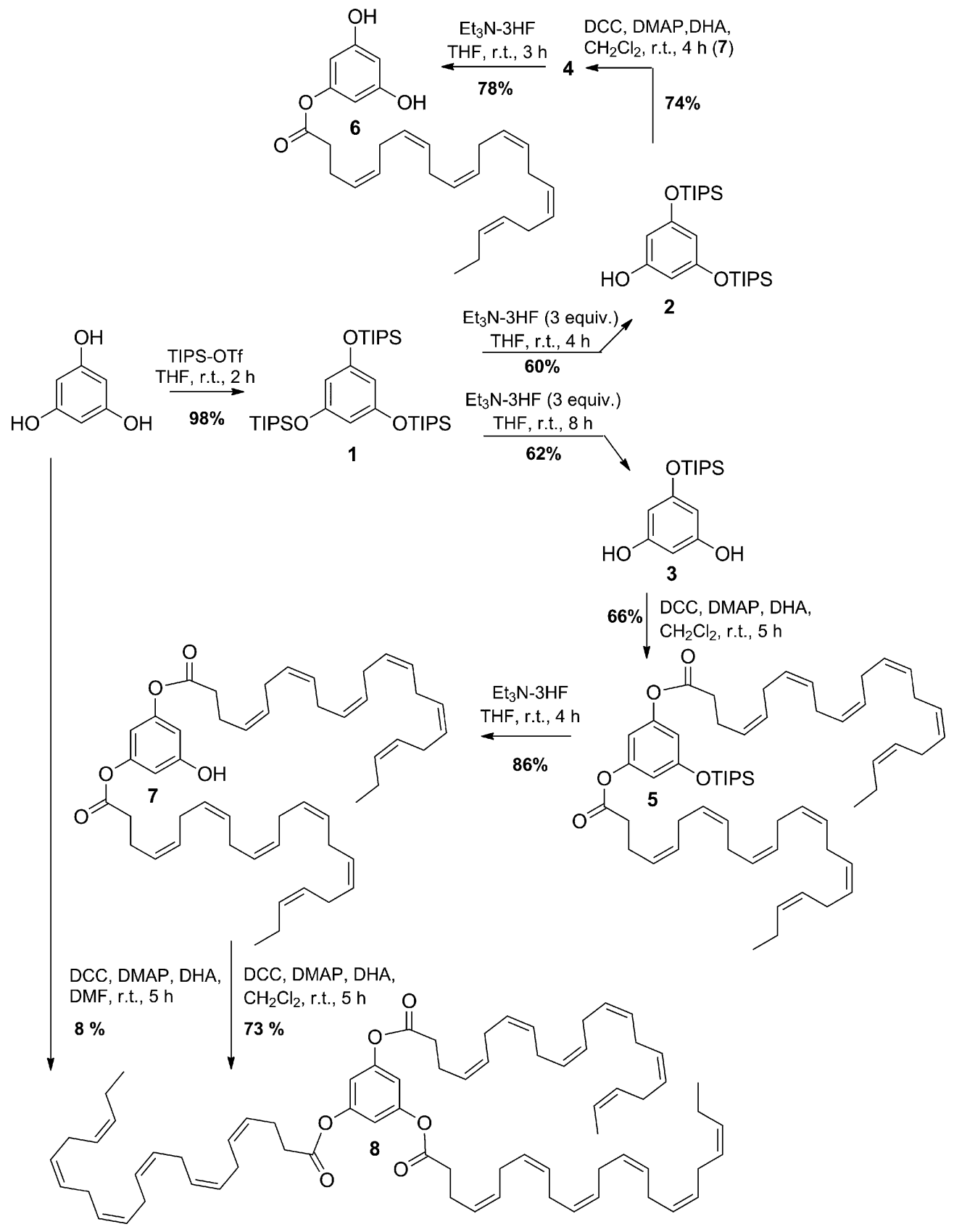


difference in the spatial configuration of fatty acids according to their degree of unsaturation. This process led to a crude mixture enriched in DHA and EPA (eicosapentaenoic acid, C20:5 n-3), which after purification on reverse phase $^{[33]}$ yielded $5 \%$ of DHA (starting from cod liver oil) with a purity of $85 \%$ [the impurities consisted of monounsaturated fatty acids such as palmitoleic (C16:1 n-7) and oleic (C18:1 n-9) acids]. Direct coupling of phloroglucinol with DHA using the classical coupling reagent dicyclohexylcarbodiimide (DCC), led to a mixture of mono-, di-, and trisubstituted conjugates, because of the increasing reactivity of the three hydroxy groups upon esterification. The yield of the monoacylation was very poor $(<10 \%)$, despite using 1 equiv. of DHA. Since this single-step strategy could not be used for the efficient preparation of lipophenol structures (with minimal consumption of DHA), we developed a strategy based on protection/deprotection of the hydroxy groups of phloroglucinol.

To obtain phloroglucinol-DHA conjugates in acceptable yield, a silyl protecting group, triisopropylsilyl (TIPS), was selected as it can be efficiently deprotected under mild conditions in the presence of ester linkages. ${ }^{[34]}$ Diprotected phloroglucinol 2 (Scheme 3) was prepared in an original way, starting with the total protection of phloroglucinol 1 using TIPS-OTf (3 equiv.) in THF, followed by a slow monodesilylation using triethylamine trihydrofluoride $\left(\mathrm{Et}_{3} \mathrm{~N} \cdot 3 \mathrm{HF} ; 3\right.$ equiv.) for $4 \mathrm{~h}$. This process allowed us to prepare intermediate 2 in $59 \%$ overall yield over two steps (only $30 \%$ could be obtained by a direct disilylation process). ${ }^{[35]}$ When the reaction time was increased (from $4 \mathrm{~h}$ to $8 \mathrm{~h}$ ), using the same amount of $\mathrm{Et}_{3} \mathrm{~N} \cdot 3 \mathrm{HF}$, monoprotected derivative 3 was obtained in $62 \%$. An attempted controlled monosilylation ( 1 equiv. TIPS-OTf, $0{ }^{\circ} \mathrm{C}$ ) gave no more than $38 \%$ yield. Next, the coupling reactions were carried out using classical DCC/DMAP (4-dimethylaminopyridine) reagents, and gave DHA conjugates 4 and 5 in 74 and $66 \%$ yields, respectively. Deprotection of the TIPS groups was carried out using $\mathrm{Et}_{3} \mathrm{~N} \cdot 3 \mathrm{HF}$ in $\mathrm{THF}$ at room temperature, and gave lipophenols 6 and 7 in 78 and $86 \%$ yields, respectively, without cleavage of the ester linkage or degradation of the polyunsaturated moiety.

Tri-DHA conjugate $\mathbf{8}$ was obtained in a much better yield starting from di-DHA-phloroglucinol conjugate 7 $(73 \%)$ than from direct coupling of phloroglucinol with DHA (3 equiv.) (only $8 \%$ ). The low coupling yield can be explained as being due to steric hindrance, or to the lower reactivity of phloroglucinol compared to its silylated derivatives.

\section{Synthesis of Alkylated DHA-Phloroglucinol Conjugates}

Alkylation, such as methylation, is a major metabolic route for dietary (poly)phenols after ingestion. ${ }^{[36]}$ Therefore, it is of interest to evaluate the influence of $O$-alkylation of the phenol group on the efficiency of carbonyl trapping. In particular, in the reaction to form chromene from phloroglucinol and trans-retinal, $C$-alkylation may be influenced by the introduction of an alkyl substituent. We hypothesize that by increasing the electron density of one of the oxygen atoms, due to an additional inductive electronic effect, the electron density in the ring could be enhanced, due to the mesomeric effect, leading to improved $C$-alkylation. To assess this effect on reactivity, we prepared a series of methylated and isopropylated phloroglucinol-DHA conjugates.

The synthesis of monoalkylated and monoprotected phloroglucinol 11 was designed to allow the introduction of the lipid moiety at the last step of the synthesis (Scheme 4). The difficulty was to perform a selective monoalkylation and/or monosilylation of the symmetrical phloroglucinol in the presence of phenol groups with identical reactivities. Using a solution of $\mathrm{MeOH}^{[37]}$ (for 9a) or $i \mathrm{PrOH}$ (for 9b) saturated with $\mathrm{HCl}$ gas, the monoalkylation could be carried out in an acceptable yield starting from phloroglucinol. The yield was optimised by lowering the proportion of dialkylated derivatives formed using a typical $O$-alkylation reagent such as dimethylsulfate or 2-bromopropane. ${ }^{[38]}$ Total protection of 9 with the TIPS protecting group (to give 10), followed by monodeprotection, gave the desired monomethylated/monoisopropylated and protected phloroglucinols 11 in two steps in yields of 58\% for the methylated compound and $54 \%$ for the isopropylated compound. Less $\mathrm{Et}_{3} \mathrm{~N} \cdot 3 \mathrm{HF}$ than was used for deprotection of $\mathbf{1}$ was needed to obtain $>60 \%$ yield, starting from alkylated phenolics $\mathbf{1 0}$. It should be noted that a direct one-step monosilylation of 9a could be achieved using TIPS-OTf at $0{ }^{\circ} \mathrm{C}$, but the yield was only $25 \%$.

Using the same coupling conditions (DCC/DMAP) as for lipophenol 6, monoalkyl phloroglucinols 11 were coupled to DHA (Scheme 5). The alkylated phloroglucinol-

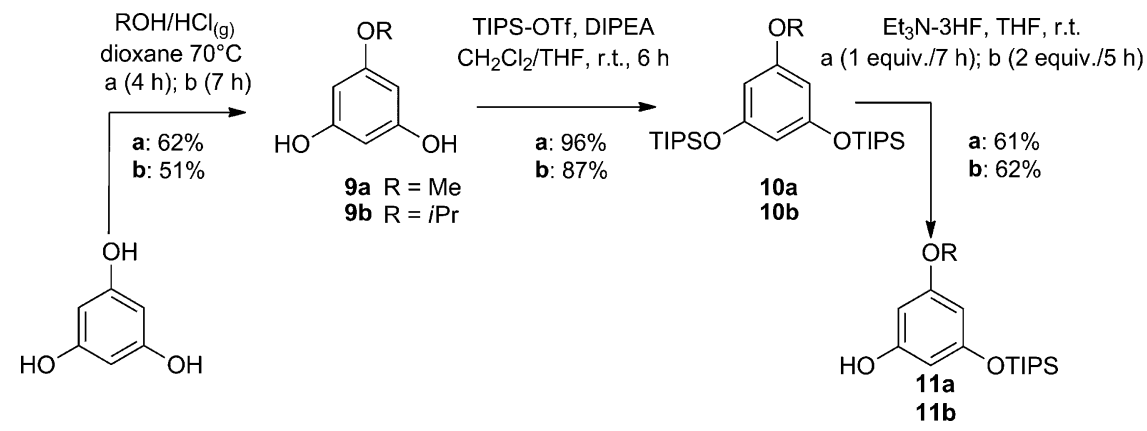

Scheme 4. Synthesis of monomethylated and monoprotected phloroglucinols 11. 


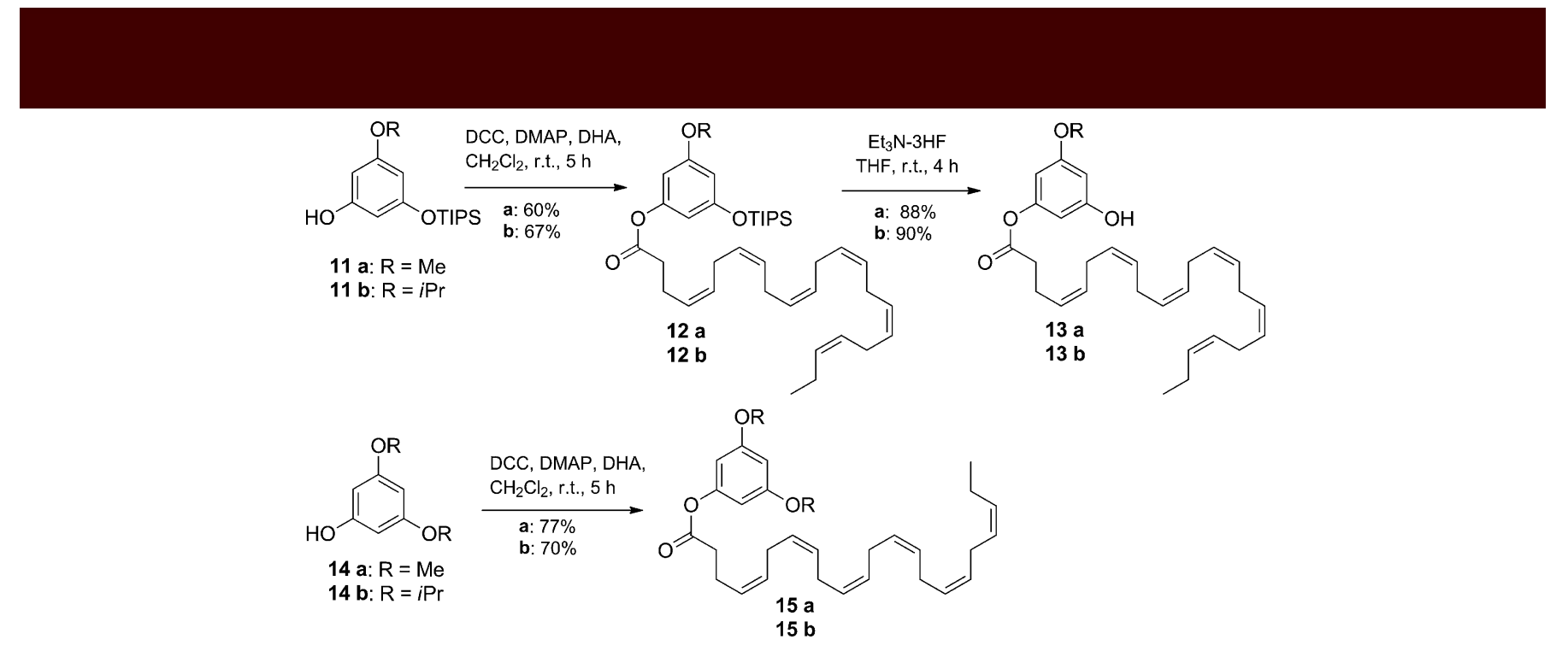

Scheme 5. Synthesis of alkylated DHA-phloroglucinol conjugates $\mathbf{1 3}$ and $\mathbf{1 5 .}$

DHA conjugates (i.e., 13) were produced in excellent to moderate yields, after removal of TIPS groups in the presence of $\mathrm{Et}_{3} \mathrm{~N} \cdot 3 \mathrm{HF}$. Dialkylated derivatives 15 were obtained in one step starting from commercially available 14a and diisopropyl-phloroglucinol $\mathbf{1 4 b}$. $^{[38]}$

\section{Synthesis of DHA-Resveratrol Conjugate}

As shown in Scheme 2, the trapping mechanism of a carbonyl stressor $(\mathrm{A} t \mathrm{R})$ by phloroglucinol requires the presence of a resorcinol pattern on the phenolic backbone. Such a framework is found in many naturally occurring polyphenols, including flavonoids, stilbenoids, and, especially, resveratrol (Scheme 6). The latter highly conjugated compound is a vinyl homologue of phloroglucinol, and is wellsuited for our purpose. Because of the importance of the reactivity of resorcinol for scavenging $\mathrm{A} t \mathrm{R}$, we decided to link the DHA moiety to the hydroxy group at the 4'-position of resveratrol, and leave the 3- and 5-hydroxy groups free to form the chromene derivative. Compared to the phloroglucinol series, the strategy envisaged for the synthesis of the stilbenoid presents additional difficulties; it requires selective protection of the phenol at the 3- and 5positions, but the three hydroxy groups of resveratrol have similar reactivities. To overcome this drawback, resveratrol was regioselectively acylated using Candida antartica lipase B (CALB or Novozyme 435), which catalyses esterification at the $4^{\prime}$-position with high selectivity. ${ }^{[39,40]}$ By carrying out this enzymatic reaction in the presence of vinyl acetate, we were able to isolate a single protected product, $4^{\prime}$ - $O$-acetylresveratrol 16, in $57 \%$ yield. The hydroxy groups at the 3and 5-positions were then protected using TIPS-OTf to give 17 , which was subjected to acetyl deprotection in the presence of a methanolic solution of $\mathrm{NaOMe}$. The deacetylated product was obtained in excellent yield. 4'-Deprotected resveratrol 18 was then coupled to DHA (to give 19), similarly to the phloroglucinol series. Compound $\mathbf{1 9}$ was then subjected to TIPS deprotection to give resveratrol-DHA conjugate $\mathbf{2 0}$ in $20 \%$ overall yield.
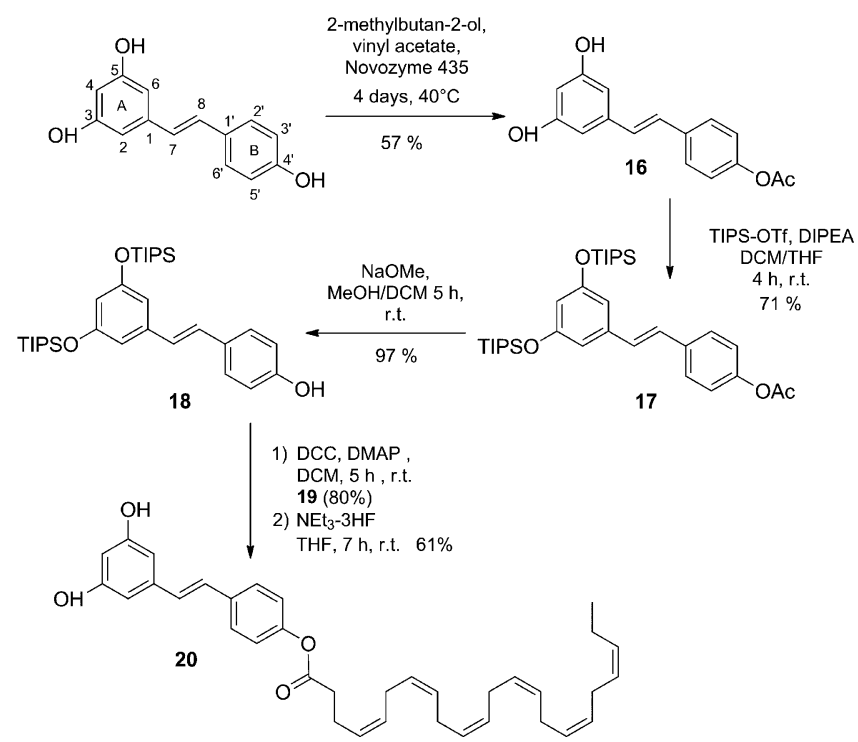

Scheme 6. Synthesis of resveratrol-DHA conjugate 20.

\section{Synthesis of 1-Phloroglucinol-2-DHA-} Glycerophosphatidylcholine Conjugate

DHA could accumulate in the retina and the brain through the specific uptake of DHA-containing lysophosphatidylcholine [1-Lyso-2-DHA-PC ( $\mathrm{PC}=$ phosphatidylcholine) or LysoPCDHA 21]. ${ }^{[29,30]}$ Since the DHA at the $s n$ 2 position of LysoPCDHA is considered to be the physiological form of this polyunsaturated LysoPC, the coupling reaction of the phenolic moiety was carried out at the $s n-1$ position. The challenge in the synthesis of such phospholipids is in avoiding internal transesterification from the $s n-2$ to the $s n-1$ position when the $s n-1$ position remains free. 
The chemical approach to obtaining a phloroglucinol-PCDHA conjugate was based on the synthesis of $s n$-1-substituted LysoPCDHA 21. This lysolecithin appears to be a suitable intermediate to access the desired lipophenol by chemical coupling with a phloroglucinol bearing an appropriate acid linker ( 22 or $\mathbf{2 3}$, Scheme 7 ). In previous research, we observed that the immobilized enzyme, lipozyme, from Mucor miehei, was able to regioselectively hydrolyse fatty acids at the $s n-1$ position of various phosphatidylcholines. This lipase, which acts specifically at the $s n-1$ and $s n-3$ positions, was tested to quantitatively obtain compound $\mathbf{2 1}$ from commercially available PC-16:0/DHA, a phosphatidylcholine having DHA at the $s n-2$ position and palmitic acid at the $s n-1$ position (Scheme 7 ). The enzymatic hydrolysis was optimised by replacing the initially tested solvent (toluene) by a mixture of $\mathrm{EtOH}$ and $\mathrm{H}_{2} \mathrm{O}$ (95:5). Using $200 \%(w / w)$ of enzyme and a reaction time of $40 \mathrm{~h}$, the reaction led to a 50\% yield of purified LysoPC-DHA 21. When another portion of enzyme was added after $9 \mathrm{~h}$, and the reaction time was decreased to $29 \mathrm{~h}$, the yield of LysoPC-DHA increased to $85 \%$. It appears that a longer reaction time facilitates the migration of the DHA to the $s n$-1 position to form 1-DHA-2-LysoPC, which, in turn, becomes a substrate for the lipozyme, resulting in the regeneration of glycerophosphocholine. HPLC monitoring of the crude material revealed that under these conditions, only a slight migration was observed after a reaction time of $29 \mathrm{~h}$ (see Supporting Information). Moreover, HMBC NMR spectroscopic analysis of isolated $\mathbf{2 1}$ confirmed the location of the DHA moiety at the $s n-2$ position by the presence of a coupling between the carbon of the carboxylic group of DHA and the $\mathrm{CH}$ proton of the glycerol moiety. With LysoPC-DHA 21 in hand, we attempted to link succinyl phloroglucinol 22 at the $s n-1$ position using DCC and DMAP. A short succinyl linker was chosen to link the lipidic and phenolic parts, so as to retain the hydrophilic properties at the $s n-1$ position, to limit the lipophilicity, and to mimic as far as possible the physiological vector LysoPCDHA. Unfortunately, the coupling reaction led to the unexpected cleavage of the succinyl ester bond, and only traces of succinyl-DHA-phosphatidylcholine devoid of the phenol moiety were identified by mass spectrometry. The lability of the succinyl linker, which regenerated succinic anhydride under acidic or basic conditions, prompted the use of a glutaryl linker. This linker was introduced onto the phloroglucinol backbone using glutaric anhydride in the presence of DMAP (to give 23, Scheme 7). The coupling step gave phospholipid conjugate 24 (65\% yield), whose TIPS groups were then deprotected. This convergent sequence of reactions led to the desired 1-glutaryl-phloroglu-

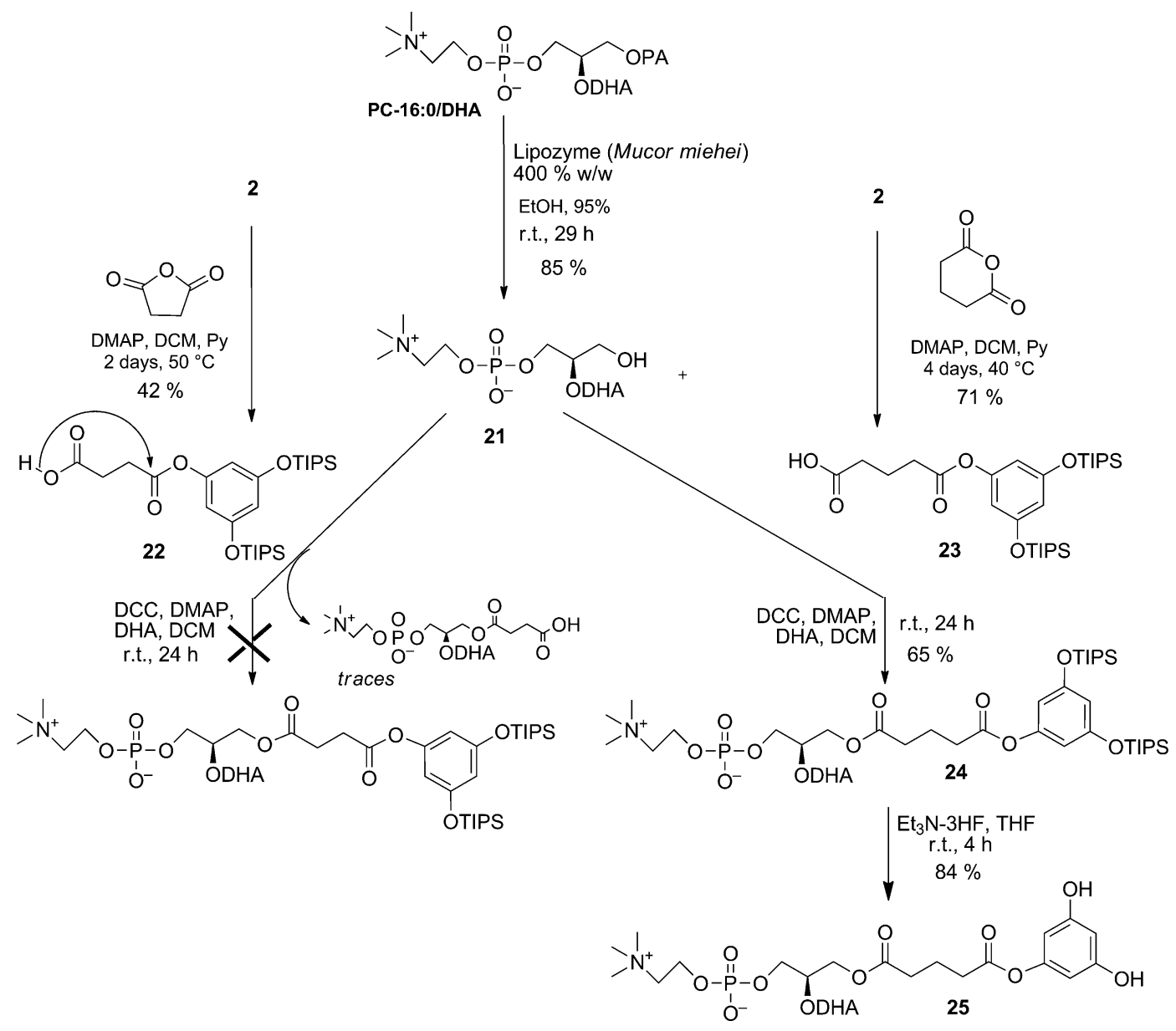

Scheme 7. Synthesis of phloroglucinol-DHA-PC conjugate 25. 
cinol-2-DHA-PC 25 in an overall yield of 20\% (six steps), starting from commercially available compounds.

\section{Effect of Lipophenol on all-trans-Retinal Toxicity in Cultured ARPE-19 Cells}

A possible protective effect of the synthesized derivatives against all-trans-retinal toxicity ${ }^{[1]}$ was evaluated in retinal pigment epithelium cell cultures (ARPE-19 cell lines). The bioassay method was based on the measurement of cell survival following challenge with the carbonyl stressor $\mathrm{A} t \mathrm{R}$ at a concentration of $25 \mu \mathrm{M}$. In control cell cultures, this concentration of $\mathrm{A} t \mathrm{R}$ was shown to reduce cell survival by 60 $70 \%$. The effects on cell viability of pre-treatment of the cultured cells with lipophenols at $10 \mu \mathrm{M}$ and $40 \mu \mathrm{M}$ are shown in Table 1 and Figure 1. The results are expressed

Table 1. ARPE-19 cell viability in the presence of lipophenol and $\mathrm{A} t \mathrm{R}$.

\begin{tabular}{lllll}
\hline \multicolumn{5}{c}{ Survival [\%] } \\
\hline & Untreated cells & 100 & $n$ \\
& A $t$ R $(25 \mu \mathrm{M})$ & $29.1 \pm 5.4$ & 7 \\
\hline Entry & Compounds & Survival at & Survival at & $n$ \\
& & $10 \mu \mathrm{M}[\%]^{[\mathrm{aa}]}$ & $40 \mu \mathrm{M}[\%]^{[\mathrm{a}]}$ & $n$ \\
\hline 1 & phloroglucinol & $35.5 \pm 3.3$ & $41.6 \pm 9.2$ & 3 \\
2 & $\mathbf{6}$ & $25.8 \pm 3.7$ & $21.9 \pm 3.8$ & 3 \\
3 & 7 & $32.1 \pm 7.1$ & $37.4 \pm 2.4$ & 3 \\
4 & $\mathbf{8}$ & $33.3 \pm 4.1$ & $47.7 \pm 3.2$ & 3 \\
5 & resveratrol & $28.8 \pm 5.8$ & $31.0 \pm 9.4$ & 4 \\
6 & $\mathbf{2 0}$ & $30.1 \pm 4.5$ & $32.1 \pm 7.3$ & 4 \\
7 & $\mathbf{1 3 a}$ & $32.6 \pm 3.7$ & $44.9 \pm 1.9$ & 3 \\
8 & $\mathbf{1 5 a}$ & $26.5 \pm 4.5$ & $26.2 \pm 2.5$ & 3 \\
9 & $\mathbf{1 3 b}$ & $43.2 \pm 7.5$ & $66.8 \pm 8.6$ & 4 \\
10 & $\mathbf{1 5 b}$ & $31.9 \pm 1.3$ & $45.7 \pm 3.3$ & 3 \\
11 & $\mathbf{2 5}$ & $28.2 \pm 2.4$ & $20.1 \pm 2.0$ & 3 \\
12 & $\mathbf{9 b}$ & $30.6 \pm 1.2$ & $32.7 \pm 1.8$ & 3 \\
13 & DHA & $23.5 \pm 2.7$ & $7.3 \pm 5.0$ & 3 \\
14 & DHA $+\mathbf{9 b}$ & $29.0 \pm 1.7$ & $10 \pm 2.6$ & 3 \\
\hline
\end{tabular}

[a] Incubation of lipophenols $1 \mathrm{~h}$ followed by AtR incubation at $25 \mu \mathrm{M}$ for $4 \mathrm{~h}$. Cell viability is measured by MTT (dimethylthiazolyldiphenyltetrazolium bromide) assay after 16-20 h. Each experiment was carried out in triplicate. as $\%$ cell survival in treated (lipophenol/all-trans-retinal) vs. untreated cells (taken as 100\%). In this bioassay, phloroglucinol showed moderate to weak activity, with a $10 \%$ increase of cell survival at $40 \mu \mathrm{m}$ (Table 1, entry 2), while the resveratrol analogues were inactive. Introduction of one DHA or one Lyso-PC-DHA onto the phloroglucinol ring structure did not increase the cell survival rate. However, increasing the number of DHA chains led to active derivatives capable of enhancing cell survival to $50 \%$, as observed for 8 (with three DHA moieties). Mono-DHA-alkylated lipophenol 13a showed comparable activity to $\mathbf{8}$. The greatest enhancement of viability ( $70 \%$ survival) was observed with 13b (monoisopropyl derivative), which showed dosedependent cytoprotection (Figure 2). Lower activities were obtained with two alkyl substituents. To validate the activity of lipophenol conjugate $\mathbf{1 3} \mathbf{b}$, a mixture of DHA and monoisopropyl phloroglucinol $\mathbf{9 b}$ was evaluated under the same conditions (pretreatment design), and this mixture was found to cause toxicity comparable to that observed with DHA alone (Table 1, entries 13 and 14). This result lends strong support to the concept that one can obtain potent cytoprotective derivatives by introduction of a PUFA moiety onto the $O$-alkylated polyphenol backbone.

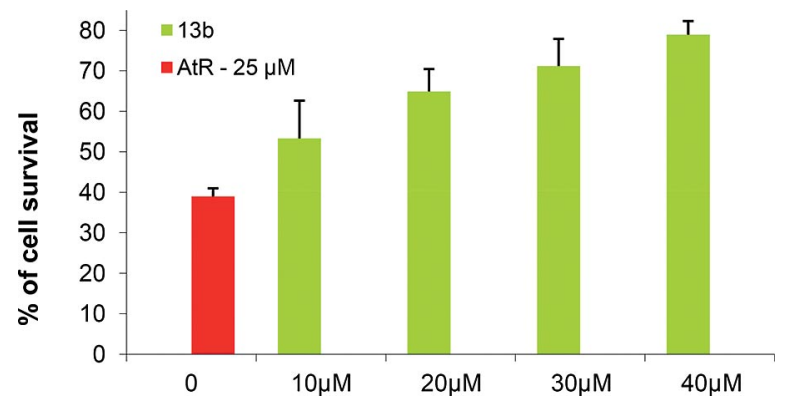

Figure 2. Dose-response activity of compound 13b; ARPE-19 cell survival in the presence of $\mathrm{A} t \mathrm{R}(25 \mu \mathrm{M})$.

To explain the protection conferred by $\mathbf{1 3 b}$ compared to the phloroglucinol-monoisopropyl compound (Table 1, entries 9 and 12), one could argue that the increased lipophilicity facilitates membrane penetration and/or that the DHA

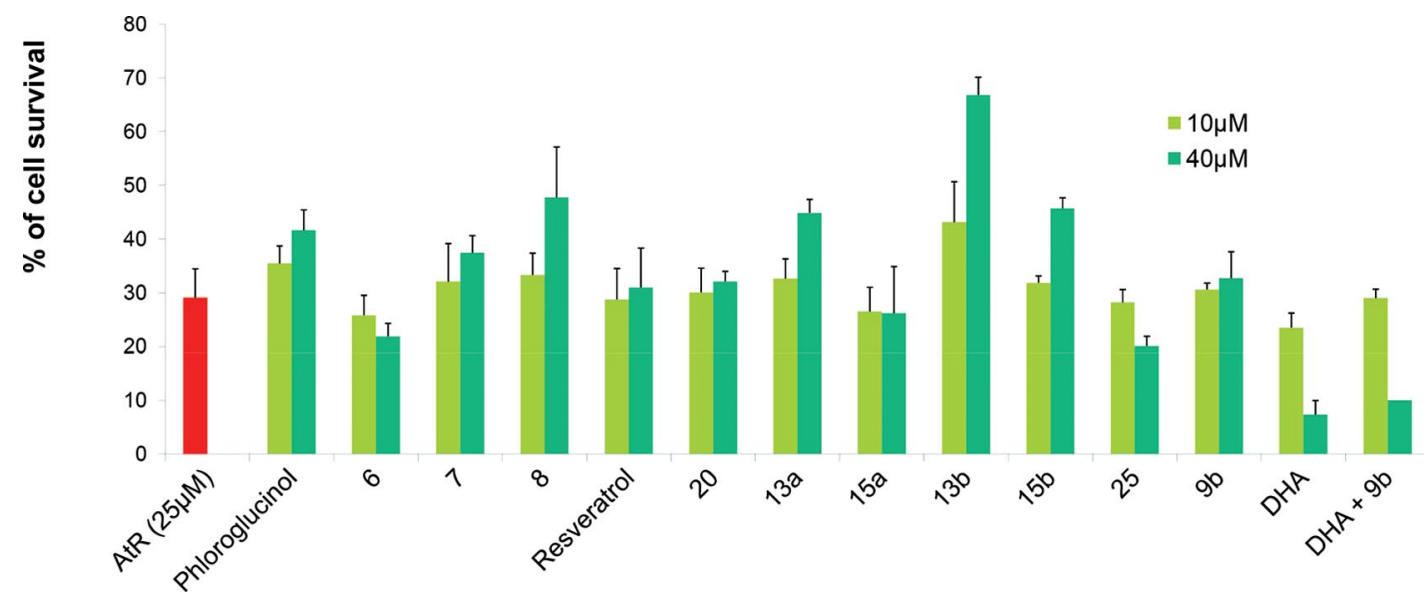

Figure 1. Protective effect of lipophenols on ARPE-19 cell line in the presence of AtR $(25 \mu \mathrm{M})$. 
fatty acyl chain may help to orientate the phloroglucinol moiety and bring it into close proximity to retinal, promoting the formation of the chromene adduct. However, this increase in reactivity is not observed with the addition of a single DHA chain on the phloroglucinol derivative (Table 1, entries 1 and 2). Moreover, although DHA-phloroglucinol conjugate $\mathbf{8}$ confers significant protection, this compound would require at least one intracellular hydrolysis to take place before the chromene adduct can be formed. Thus, the details of the cytoprotection mechanism need further study. Whether the protection involves a direct reaction with trans-retinal or indirect influences on cellular enzymatic systems remains an open question.

\section{Conclusions}

We have developed efficient synthetic routes to conjugates of phenolic derivatives with DHA, an n-3 PUFA. The phloroglucinol-DHA series of eight new compounds relies on an original selective protection process using TIPS protecting groups. The synthesis of lipophenols bearing the resveratrol motif was achieved through chemical protection as well as enzymatic means and control of reaction conditions, which allowed the introduction of DHA specifically at the $4^{\prime}$-position. Finally, the introduction of phloroglucinol at the $s n-1$ position of a DHA-glycerophosphocholine conjugate was realized for the first time, using an efficient enzymatic route to LysoPC-DHA and the selection of an appropriate glutaryl linker.

The protective effect of the lipophenol derivatives was evaluated in cultured retinal epithelial cells challenged with a toxic concentration of trans-retinal. One of the compounds showed a significant cytoprotective effect, increasing cell survival by up to $40 \%$ compared to untreated cells (13b at $40 \mu \mathrm{M})$. The importance of the lipid portion for the activity of this derivative was confirmed by comparison with similar compounds lacking the lipid component. These results are promising, especially in light of the work by Maeda et al., who reported that 5-ASA (5-aminosalicylic acid; $300 \mu \mathrm{M}$ ) increased cell survival by $43 \%$ in a similar bioassay with ARPE-19 cells exposed to A $t$ R. ${ }^{[41]}$

The mechanism of the cytoprotective effect of adding DHA chains to the phloroglucinol ring structure remains to be determined. The modification may enhance cell penetration (by passive diffusion or active transport), or another mechanism could be involved. This is currently under investigation in our laboratory, and the findings will be reported in due course.

This work paves the way for the synthesis of new polyunsaturated fatty acyl derivatives ester-linked to appropriate phenolic ring structures. The results should be of interest to researchers studying the role of oxidative and carbonyl stress in various pathological conditions. According to a recent report, dietary supplementation with high dose DHA appeared to significantly improve the visual acuity of an AMD patient. ${ }^{[42]}$ New lipophenols that combine PUFA and carbonyl scavenging activity in the same molecule may have therapeutic applications in the treatment of retinal and neurodegenerative disorders.

\section{Experimental Section}

\section{Synthesis of Lipophenols}

Obtaining DHA from Cod Liver Oil: Commercially sourced cod liver oil ( $5 \mathrm{~g}$, Cooper, France) was dissolved in a mixture of ethanol and water $(95: 5 ; 35 \mathrm{~mL})$ in the presence of $\mathrm{NaOH}(1.50 \mathrm{~g})$ under an argon atmosphere. The mixture was protected from the light with foil, and heated at $82{ }^{\circ} \mathrm{C}$ for $2 \mathrm{~h}$. The ethanolic fraction was evaporated, and the residue was dissolved in hexane $(30 \mathrm{~mL})$ after heating. Then water $(25 \mathrm{~mL})$ was added to the organic layer, and unsaponifiable material was removed by repeated hexane extraction $(4 \times 30 \mathrm{~mL})$ of the aqueous phase. The aqueous phase containing the soaps was acidified to $\mathrm{pH} 2$ using $\mathrm{HCl}$ solution $(50 \%)$. The fatty acids were extracted with hexane $(4 \times 25 \mathrm{~mL})$. The organic phase was concentrated under reduced pressure to give the crude fatty acids (4.62 g) as an oil. Urea (13.86 g) and ethanol (95\%; $55 \mathrm{~mL}$ ) were added to the crude residue. The mixture was heated at $60-70{ }^{\circ} \mathrm{C}$, protected from the light, until it turned into a clear homogeneous solution. The mixture was then returned to room temperature, and then cooled to $4{ }^{\circ} \mathrm{C}$ for $24 \mathrm{~h}$. The resulting crystals were separated from the liquid by filtration. The filtrate was diluted with water $(35 \mathrm{~mL})$, and acidified to $\mathrm{pH} 4-5$ with $\mathrm{HCl}$ solution $(6 \mathrm{~N})$. Hexane $(70 \mathrm{~mL})$ was added, and the solution was stirred thoroughly for $1 \mathrm{~h}$. The hexane layer containing the liberated fatty acids was separated from the aqueous layer, and washed with water $(3 \times 40 \mathrm{~mL})$. The organic phase was dried with $\mathrm{Na}_{2} \mathrm{SO}_{4}$, and concentrated under reduced pressure to give a crude mixture of PUFAs (820 mg), which was purified by preparative HPLC [column Atlantis Prep OBD ${ }^{\mathrm{TM}} 10 \mu \mathrm{m}(19 \times 250 \mathrm{~mm}), \mathrm{H}_{2} \mathrm{O} / \mathrm{MeOH}, 13: 87$ isocratic, detection $217 \mathrm{~nm}$ ] to give pure DHA $(266 \mathrm{mg}, 5 \% \mathrm{w} / \mathrm{w}) .{ }^{1} \mathrm{H}$ NMR (500 MHz, $\left.\mathrm{CDCl}_{3}\right): \delta=5.43-5.30(\mathrm{~m}, 12 \mathrm{H}, \mathrm{CH}=\mathrm{CH}), 2.85$ $2.80\left(\mathrm{~m}, 10 \mathrm{H}, \mathrm{CH}_{2}\right.$ bis-allylic), 2.42-2.40 (m, $4 \mathrm{H}, \mathrm{CH}_{2}-\mathrm{C}=\mathrm{O}, \mathrm{CH}_{2}$ allylic), 2.07 (quint, $J=7.5 \mathrm{~Hz}, 2 \mathrm{H}, \mathrm{CH}_{2}$ allylic), 0.98 (t, $J=$ $\left.7.5 \mathrm{~Hz}, 3 \mathrm{H}, \mathrm{CH}_{3}\right)$ ppm. MS (ESI): $m / z=327[\mathrm{M}-\mathrm{H}]^{-}$

2-Methyl-2-[(1E,3E,5E)-4-methyl-6-(2,6,6-trimethylcyclohex-1enyl)-hexa-1,3,5-trienyl]-2H-chromene-5,7-diol (Chromene A): transRetinal (200 mg, $0.35 \mathrm{mmol})$ was dissolved in ethanol $(8 \mathrm{~mL})$, and phloroglucinol $(48.28 \mathrm{mg}, 0.35 \mathrm{mmol})$ and acetic acid $(40 \mu \mathrm{L}$, $0.35 \mathrm{mmol}$ ) were added to the stirred solution. The reaction mixture was stirred at room temperature for $48 \mathrm{~h}$, protected from light with foil. The solvent was removed under reduced pressure, the residue was dissolved in EtOAc $(20 \mathrm{~mL})$, and this solution was washed with water $(10 \mathrm{~mL})$. The organic layer was dried with $\mathrm{MgSO}_{4}$, and concentrated under reduced pressure. The residue was purified by chromatography on silica gel (pentane/EtOAc, 90:10 to $85: 15)$ to give Chromene A $(112.4 \mathrm{mg}, 41 \%)$ as a solid contaminated with a by-product (13\%). Chromene $\mathbf{A}$ was isolated after purification by preparative HPLC to allow full characterization (gradient of hexane/EtOAc, $t_{0^{\prime}}=100 / 0, t_{15^{\prime}}=90 / 10, t_{45^{\prime}}=80 / 20$, $t_{75^{\prime}}=70 / 30 ; 15 \mathrm{~mL} / \mathrm{min}$, column Luna $5 \mu$ Silica $100 \mathrm{~A}$ $250 \times 21.20 \mathrm{~mm}$, detection $254 \mathrm{~nm}) . R_{\mathrm{f}}\left(\mathrm{CH}_{2} \mathrm{Cl}_{2} / \mathrm{MeOH}, 95: 5\right): 0.4$. ${ }^{1} \mathrm{H}$ NMR (500 MHz, [D 4 methanol): $\delta=6.63$ (dd, $J=11.5, J=$ $15.5 \mathrm{~Hz}, 1 \mathrm{H}, 11-\mathrm{H}), 6.63(\mathrm{~d}, J=10.0 \mathrm{~Hz}, 1 \mathrm{H}, 15-\mathrm{H}), 6.14(\mathrm{~d}, J=$ $16.5 \mathrm{~Hz}, 1 \mathrm{H}, 7-\mathrm{H}), 6.03(\mathrm{~d}, J=16.5 \mathrm{~Hz}, 1 \mathrm{H}, 8-\mathrm{H}), 5.98$ (d, $J=$ $11.0 \mathrm{~Hz}, 1 \mathrm{H}, 10-\mathrm{H}), 5.85$ and $5.81(\mathrm{~d}, J=2.0 \mathrm{~Hz}, 1 \mathrm{H}$, and $\mathrm{d}, J=$ $2.5 \mathrm{~Hz}, 1 \mathrm{H}, 18-\mathrm{H}$ and $20-\mathrm{H}), 5.75(\mathrm{~d}, J=15.0 \mathrm{~Hz}, 1 \mathrm{H}, 12-\mathrm{H})$, $5.39(\mathrm{~d}, J=10.0 \mathrm{~Hz}, 1 \mathrm{H}, 14-\mathrm{H}), 2.02-2.00\left[\mathrm{~m}, 2 \mathrm{H}, 4-\mathrm{H}\left(\mathrm{CH}_{2}\right)\right]$, 
$1.86\left[\mathrm{~s}, 3 \mathrm{H}, 25-\mathrm{H}\left(\mathrm{CH}_{3}\right)\right], 1.68$ [s, $\left.3 \mathrm{H}, 24-\mathrm{H}\left(\mathrm{CH}_{3}\right)\right], 1.67-1.60[\mathrm{~m}$, $\left.2 \mathrm{H}, 3-\mathrm{H}\left(\mathrm{CH}_{2}\right)\right], 1.49\left[\mathrm{~s}, 3 \mathrm{H}, 26-\mathrm{H}\left(\mathrm{CH}_{3}\right)\right], 1.48-1.46[\mathrm{~m}, 2 \mathrm{H}, 2-\mathrm{H}$ $\left.\left(\mathrm{CH}_{2}\right)\right], 1.00\left[\mathrm{~s}, 6 \mathrm{H}, 22-\mathrm{H}, 23-\mathrm{H}\left(\mathrm{CH}_{3}\right)\right] \mathrm{ppm} .{ }^{13} \mathrm{C} \mathrm{NMR}(125 \mathrm{MHz}$, $\left.\mathrm{CDCl}_{3}\right): \delta=159.7(\mathrm{C}-19), 156.4(\mathrm{C}-21 / \mathrm{C}-17), 139.1$ (C-8), $139.0(\mathrm{C}-$ 6), 137.1 (C-12), 137.0 (C-9), 130.4 (C-10), 129.9 (C-5), 127.6 (C7), 126.3 (C-15), 123.1 (C-14), 119.1 (C-11), 103.9 (C-16), 96.3 (C20/C-18), 78.5 (C-13), 40.7 (C-2), 35.1 (C-1), 33.9 (C-4), 29.3 (C22/C-23), 27.6 (C-26), 21.8 (C-24), 20.3 (C-3), 12.6 (C-25) ppm. HRMS (ESI-TOF): calcd. for $\mathrm{C}_{26} \mathrm{H}_{31} \mathrm{O}_{3}[\mathrm{M}-\mathrm{H}]^{-} 391.2278$; found 391.2272. HPLC [Atlantis C18 $5 \mu \mathrm{m}(4.6 \times 250 \mathrm{~mm}), \mathrm{H}_{2} \mathrm{O}(0.1 \%$ $\left.\mathrm{CF}_{3} \mathrm{COOH}\right) / \mathrm{MeCN}, t_{0^{\prime}}=25 / 75, t_{25^{\prime}}=20 / 80, t_{28^{\prime}}=0 / 100, t_{33^{\prime}}=0 /$ 100 , detection $298 \mathrm{~nm}$ ]: $t_{\mathrm{R}}=11.26 \mathrm{~min}$.

General Procedure for Coupling of DHA with Polyphenolic Derivatives: DHA (1.1 equiv., $0.30 \mathrm{mmol}$ ) and each of the phenolic derivatives (1.0 equiv., $0.27 \mathrm{mmol}$ ) were dissolved in dry $\mathrm{CH}_{2} \mathrm{Cl}_{2}(6 \mathrm{~mL})$. DCC ( 1.1 equiv., $0.30 \mathrm{mmol})$ and DMAP ( 0.1 equiv., $0.03 \mathrm{mmol}$ ) were added, and the reaction mixture was stirred at room temperature for $5 \mathrm{~h}$ under nitrogen. The mixture was left at $4{ }^{\circ} \mathrm{C}$ for $2 \mathrm{~h}$ to induce crystallization of dicyclohexylurea. The urea residue was then removed by filtration, and the filtrate was washed with water and brine. The organic layer was dried with $\mathrm{MgSO}_{4}$, and concentrated under reduced pressure. Purification of the crude material by chromatography on silica gel gave the desired lipophenol.

General Procedure for Deprotection of the TIPS Protecting Group from DHA-Polyphenol Derivatives: The protected DHA-polyphenol (1.0 equiv., $0.19 \mathrm{mmol}$ ) was dissolved in anhydrous THF $(13 \mathrm{~mL})$, and triethylammonium trihydrofluoride $\left(\mathrm{Et}_{3} \mathrm{~N} \cdot 3 \mathrm{HF}\right.$; 3 equiv., $0.57 \mathrm{mmol}$ for monoprotected compounds, or 6 equiv., $1.14 \mathrm{mmol}$ for diprotected compounds) was added dropwise. The mixture was stirred at room temperature for 4 to $6 \mathrm{~h}$, until the reaction was complete. EtOAc $(40 \mathrm{~mL})$ was added to the mixture, and the organic layer was washed with water $(15 \mathrm{~mL})$ and brine $(15 \mathrm{~mL})$. The organic phase was dried $\left(\mathrm{MgSO}_{4}\right)$ and concentrated under vacuum. The residue was purified by chromatography on silica gel to give the deprotected lipophenol.

1,3,5-Tris(triisopropylsilyloxy)benzene (1): Phloroglucinol (1 g, $7.90 \mathrm{mmol})$ was dissolved in dry THF $(60 \mathrm{~mL})$, and triethylamine (3.68 mL, $23 \mathrm{mmol}$ ) and triisopropylsilyl trifluoromethanesulfonate (TIPS-OTf; $7 \mathrm{~mL}, 23 \mathrm{mmol}$ ) were added dropwise. The reaction mixture was stirred at room temperature for $2 \mathrm{~h}$. EtOAc $(60 \mathrm{~mL})$ was added to the mixture, and the organic layer was washed with water $(40 \mathrm{~mL})$ and brine $(40 \mathrm{~mL})$. The organic phase was dried $\left(\mathrm{MgSO}_{4}\right)$, and concentrated under vacuum. The residue was purified by chromatography on silica gel (hexane/EtOAc, 99:1) to give triprotected phloroglucinol $1\left(4.64 \mathrm{~g}, 98 \%\right.$ ) as a yellow oil. $R_{\mathrm{f}}$ (pentane): 0.28. ${ }^{1} \mathrm{H}$ NMR (500 MHz, $\left.\mathrm{CDCl}_{3}\right): \delta=6.07$ (s, $3 \mathrm{H}, \mathrm{CH}_{\text {aro }}$ ), 1.27-1.18 (m, $9 \mathrm{H}, \mathrm{CH}-\mathrm{Si}), 1.09$ [d, $J=7.3 \mathrm{~Hz}, 54 \mathrm{H},\left(\mathrm{CH}_{3}\right)_{2} \mathrm{C}$ ] ppm ${ }^{13} \mathrm{C}$ NMR $\left(125 \mathrm{MHz}, \mathrm{CDCl}_{3}\right): \delta=157.4,105.8,18.1$, 12.8 ppm. HRMS (ESI-TOF): calcd. for $\mathrm{C}_{33} \mathrm{H}_{67} \mathrm{O}_{3} \mathrm{Si}_{3}[\mathrm{M}+\mathrm{H}]^{+}$ 595.4392; found 595.4395 .

3,5-Bis(triisopropylsilyloxy)phenol (2): Triprotected phloroglucinol $1(5.01 \mathrm{~g}, 8.43 \mathrm{mmol})$ was dissolved in dry THF $(200 \mathrm{~mL})$. $\mathrm{Et}_{3} \mathrm{~N} \cdot 3 \mathrm{HF}(2.90 \mathrm{~mL}, 17.70 \mathrm{mmol})$ was added dropwise, and the mixture was stirred at room temperature for $4 \mathrm{~h}$. The reaction was followed by TLC, and it was stopped so as to avoid as much as possible the formation of the dideprotected compound. EtOAc $(200 \mathrm{~mL})$ was added to the mixture, and the organic layer was washed with water $(200 \mathrm{~mL})$ and brine $(100 \mathrm{~mL})$. The organic phase was dried $\left(\mathrm{MgSO}_{4}\right)$ and concentrated under vacuum. The residue was purified by chromatography on silica gel (pentane/ EtOAc, 95:5) to give diprotected phloroglucinol 2 (2.25 g, 60\%) as a yellow oil. Monoprotected derivative 3 was isolated $(0.45 \mathrm{~g}, 18 \%)$ as a white solid. Data for 2: $R_{\mathrm{f}}$ (pentane/EtOAc, 80:20): $0.8 .{ }^{1} \mathrm{H}$ $\operatorname{NMR}\left(500 \mathrm{MHz}, \mathrm{CDCl}_{3}\right): \delta=6.03\left(\mathrm{t}, J=2.0 \mathrm{~Hz}, 1 \mathrm{H}, \mathrm{CH}_{\mathrm{aro}}\right)$, $6.01\left(\mathrm{~d}, J=2.0 \mathrm{~Hz}, 2 \mathrm{H}, \mathrm{CH}_{\text {aro }}\right), 1.27-1.19$ (m, $\left.6 \mathrm{H}, \mathrm{CH}-\mathrm{Si}\right), 1.09$ $\left[\mathrm{d}, J=7.3 \mathrm{~Hz}, 36 \mathrm{H},\left(\mathrm{CH}_{3}\right)_{2} \mathrm{C}\right] \mathrm{ppm} .{ }^{13} \mathrm{C} \mathrm{NMR}\left(125 \mathrm{MHz}, \mathrm{CDCl}_{3}\right)$ : $\delta=157.8,157.0,105.1,101.1,18.1,12.8$ ppm. HRMS (ESI-TOF): calcd. for $\mathrm{C}_{24} \mathrm{H}_{45} \mathrm{O}_{3} \mathrm{Si}_{2}[\mathrm{M}-\mathrm{H}]^{-}$437.2907; found 437.2911.

5-(Triisopropylsilyloxy)benzene-1,3-diol (3): Triprotected phloroglucinol 1 (200 mg, $0.33 \mathrm{mmol})$ was dissolved in dry THF $(12 \mathrm{~mL})$. $\mathrm{Et}_{3} \mathrm{~N} \cdot 3 \mathrm{HF}(164 \mu \mathrm{L} \mathrm{mL}, 1 \mathrm{mmol})$ was added dropwise. The reaction was followed by TLC, and it was stopped so as to limit as much as possible the formation of the monodeprotected derivative. The mixture was stirred for $6 \mathrm{~h}$ at room temperature, then further $\mathrm{Et}_{3} \mathrm{~N} \cdot 3 \mathrm{HF}$ ( 1 equiv.) was added. The reaction was stopped after $8 \mathrm{~h}$. EtOAc $(15 \mathrm{~mL})$ was added to the mixture, and the organic layer was washed with water $(10 \mathrm{~mL})$ and brine $(10 \mathrm{~mL})$. The organic phase was dried $\left(\mathrm{MgSO}_{4}\right)$, and concentrated under vacuum. The residue was purified by chromatography on silica gel (pentane/ EtOAc, 95:5) to give monoprotected phloroglucinol 3 (59 mg, 62\%) as a white solid. Diprotected derivative 2 was isolated (20 mg, 13\%) as a yellow oil. Data for 3: $R_{\mathrm{f}}$ (hexane/EtOAc, 70:30): 0.34. ${ }^{1} \mathrm{H}$ $\operatorname{NMR}\left(500 \mathrm{MHz}, \mathrm{CDCl}_{3}\right): \delta=5.99\left(\mathrm{~d}, J=2.0 \mathrm{~Hz}, 2 \mathrm{H}, \mathrm{CH}_{\text {aro }}\right)$, $6.01\left(\mathrm{t}, J=2.0 \mathrm{~Hz}, 1 \mathrm{H}, \mathrm{CH}_{\mathrm{aro}}\right), 1.27-1.18$ (m, $\left.3 \mathrm{H}, \mathrm{CH}-\mathrm{Si}\right), 1.08$ $\left[\mathrm{d}, J=7.5 \mathrm{~Hz}, 18 \mathrm{H},\left(\mathrm{CH}_{3}\right)_{2} \mathrm{C}\right] \mathrm{ppm} .{ }^{13} \mathrm{C} \mathrm{NMR}\left(125 \mathrm{MHz}, \mathrm{CDCl}_{3}\right)$ : $\delta=158.2,157.3,100.5,96.5,18.0,12.8$ ppm. HRMS (ESI-TOF): calcd. for $\mathrm{C}_{15} \mathrm{H}_{25} \mathrm{O}_{3} \mathrm{Si}[\mathrm{M}-\mathrm{H}]^{-}$281.1573; found 281.1570.

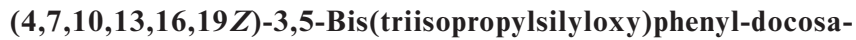
4,7,10,13,16,19-hexaenoate (4): Coupling of di-TIPS-phloroglucinol 2 (130 mg, $0.29 \mathrm{mmol})$ and DHA (104 mg, $0.32 \mathrm{mmol})$ was carried out according to the general procedure to give 4 (164 mg, $74 \%$ ) as a colourless oil after purification by silica gel chromatography (hexane/EtOAc, 99.7:0.3 to 99:1). $R_{\mathrm{f}}$ (hexane/EtOAc, 99:1): 0.23. ${ }^{1} \mathrm{H}$ NMR (500 MHz, $\left.\mathrm{CDCl}_{3}\right): \delta=6.29-6.27\left(\mathrm{~m}, 1 \mathrm{H}, \mathrm{CH}_{\mathrm{aro}}\right)$, 6.25-6.24 (m, $\left.2 \mathrm{H}, \mathrm{CH}_{\text {aro }}\right), 5.45-5.30(\mathrm{~m}, 12 \mathrm{H}, \mathrm{CH}=\mathrm{CH}), 2.87-$ $2.81\left(\mathrm{~m}, 10 \mathrm{H}, \mathrm{CH}_{2}\right.$ bis-allylic), 2.57 (t, $J=7.3 \mathrm{~Hz}, 2 \mathrm{H}, \mathrm{CH}_{2^{-}}$ $\mathrm{C}=\mathrm{O}$ ), 2.52-2.48 (m, $2 \mathrm{H}, \mathrm{CH}_{2}$ allylic), 2.07 (quint, $J=7.5 \mathrm{~Hz}, 2$ $\mathrm{H}, \mathrm{CH}_{2}$ allylic), 1.26-1.18 (m, $\left.6 \mathrm{H}, \mathrm{CH}-\mathrm{Si}\right), 1.08$ [d, $J=7.5 \mathrm{~Hz}, 36$ $\left.\mathrm{H},\left(\mathrm{CH}_{3}\right)_{2} \mathrm{C}\right], 0.97\left(\mathrm{t}, J=7.5 \mathrm{~Hz}, 3 \mathrm{H}, \mathrm{CH}_{3}\right) \mathrm{ppm} .{ }^{13} \mathrm{C} \mathrm{NMR}$ $\left(125 \mathrm{MHz}, \mathrm{CDCl}_{3}\right): \delta=171.1,157.1,151.8,132.0,129.6,128.6$, $128.3,128.3,128.2,128.1,128.1,128.0,127.9,127.0,109.2,106.9$, $34.4,25.6,25.5,22.7,20.6,17.8,14.2,12.7$ ppm. HRMS (ESITOF): calcd. for $\mathrm{C}_{46} \mathrm{H}_{77} \mathrm{O}_{4} \mathrm{Si}_{2}[\mathrm{M}+\mathrm{H}]^{+}$749.5354; found 749.5363 .

$\left(4,4^{\prime}, 7,7^{\prime}, 10,10^{\prime}, 13,13^{\prime}, 16,16^{\prime}, 19,19^{\prime} Z\right)$-5-(Triisopropylsilyloxy)-1,3phenylene-didocosa-4,7,10,13,16,19-hexaenoate (5): Coupling of mono-TIPS-phloroglucinol $3(86 \mathrm{mg}, 0.30 \mathrm{mmol})$ and DHA (200 $\mathrm{mg}, 0.60 \mathrm{mmol}$ ) was carried out according to the general procedure to give $5(183 \mathrm{mg}, 66 \%)$ as a colourless oil after purification by silica gel chromatography (pentane/EtOAc, 98:2). $R_{\mathrm{f}}$ (pentane/ EtOAc, 98:2): 0.34. ${ }^{1} \mathrm{H}$ NMR (500 MHz, $\left.\mathrm{CDCl}_{3}\right): \delta=6.51(\mathrm{~s}, 3 \mathrm{H}$, $\mathrm{CH}_{\text {aro }}$ ), 5.47-5.28 (m, $\left.24 \mathrm{H}, \mathrm{CH}=\mathrm{CH}\right), 2.87-2.80\left(\mathrm{~m}, 20 \mathrm{H}, \mathrm{CH}_{2}\right.$ bis-allylic), 2.60-2.57 (m, $\left.4 \mathrm{H}, \mathrm{CH}_{2}-\mathrm{C}=\mathrm{O}\right), 2.51-2.47\left(\mathrm{~m}, 4 \mathrm{H}, \mathrm{CH}_{2}\right.$ allylic), 2.07 (quint, $J=7.5 \mathrm{~Hz}, 4 \mathrm{H}, \mathrm{CH}_{2}$ allylic), $1.27-1.22(\mathrm{~m}, 3$ $\mathrm{H}, \mathrm{CH}-\mathrm{Si}), 1.08$ [d, $\left.J=7.5 \mathrm{~Hz}, 18 \mathrm{H},\left(\mathrm{CH}_{3}\right)_{2} \mathrm{C}\right], 0.97$ (t, $J=7.5 \mathrm{~Hz}$, $\left.6 \mathrm{H}, \mathrm{CH}_{3}\right)$ ppm. ${ }^{13} \mathrm{C} \mathrm{NMR}\left(125 \mathrm{MHz}, \mathrm{CDCl}_{3}\right): \delta=170.9,157.0$, $151.4,132.0,129.7,128.5,128.3,128.2,128.2,128.1,128.0,127.9$, $127.8,127.4,127.0,110.9,108.0,34.2,25.6,25.6,25.5,22.6,20.5$, $17.8,14.2,12.5 \mathrm{ppm}$. HRMS (ESI-TOF): calcd. for $\mathrm{C}_{59} \mathrm{H}_{87} \mathrm{O}_{5} \mathrm{Si}$ $[\mathrm{M}+\mathrm{H}]^{+}$903.6317; found 903.6321.

$(4,7,10,13,16,19 Z)-3,5-D i h y d r o x y p h e n y l-d o c o s a-4,7,10,13,16,19-$ hexaenoate (6): Deprotection of protected DHA-phloroglucinol 4 (50 mg, $0.07 \mathrm{mmol}$ ) was carried out according to the general procedure to give $6(23 \mathrm{mg}, 78 \%)$ as a colourless oil after purification by silica gel chromatography (hexane/EtOAc, 9:1 to $75: 25$ ). $R_{\mathrm{f}}$ (hex- 
ane/EtOAc, 70:30): 0.36. ${ }^{1} \mathrm{H}$ NMR (500 MHz, $\left.\mathrm{CDCl}_{3}\right): \delta=6.06$ (s, $\left.3 \mathrm{H}, \mathrm{CH}_{\text {aro }}\right), 5.48-5.28(\mathrm{~m}, 12 \mathrm{H}, \mathrm{CH}=\mathrm{CH}), 2.87-2.79(\mathrm{~m}, 10 \mathrm{H}$, $\mathrm{CH}_{2}$ bis-allylic), 2.63 (t, $\left.J=7.0 \mathrm{~Hz}, 2 \mathrm{H}, \mathrm{CH}_{2}-\mathrm{C}=\mathrm{O}\right), 2.53-2.48(\mathrm{~m}$, $2 \mathrm{H}, \mathrm{CH}_{2}$ allylic), 2.06 (quint, $J=7.5 \mathrm{~Hz}, 2 \mathrm{H}, \mathrm{CH}_{2}$ allylic), 0.96 (t, $\left.J=7.5 \mathrm{~Hz}, 3 \mathrm{H}, \mathrm{CH}_{3}\right) \mathrm{ppm} .{ }^{13} \mathrm{C} \mathrm{NMR}\left(125 \mathrm{MHz}, \mathrm{CDCl}_{3}\right): \delta=$ $172.7,157.3,151.8,132.0,129.9,128.6,128.4,128.3,128.3,128.1$, 128.0, 127.8, 127.8, 127.2, 127.0, 101.9, 101.1, 34.3, 25.6, 25.6, 25.6, 25.5, 22.7, 20.5, 14.2 ppm. HRMS (ESI-TOF): calcd. for $\mathrm{C}_{28} \mathrm{H}_{35} \mathrm{O}_{4}$ $[\mathrm{M}-\mathrm{H}]^{-}$435.2535; found 435.2538.

$\left(4,4^{\prime}, 7,7^{\prime}, 10,10^{\prime}, 13,13^{\prime}, 16,16^{\prime}, 19,19^{\prime} Z\right)$-5-Hydroxy-1,3-phenylene Didocosa-4,7,10,13,16,19-hexaenoate (7): Deprotection of protected DHA-phloroglucinol 5 (168 mg, $0.19 \mathrm{mmol})$ was carried out according to the general procedure to give $7(119 \mathrm{mg}, 86 \%)$ as a colourless oil after purification by silica gel chromatography (hexane/EtOAc, 90:10). $R_{\mathrm{f}}$ (hexane/EtOAc, 90:10): 0.19. ${ }^{1} \mathrm{H}$ NMR $\left(500 \mathrm{MHz}, \mathrm{CDCl}_{3}\right): \delta=6.48\left(\mathrm{~s}, 3 \mathrm{H}, \mathrm{CH}_{\text {aro }}\right), 5.48-5.29(\mathrm{~m}, 24 \mathrm{H}$, $\mathrm{CH}=\mathrm{CH}), 2.88-2.80\left(\mathrm{~m}, 20 \mathrm{H}, \mathrm{CH}_{2}\right.$ bis-allylic), $2.60(\mathrm{t}, J=7.1 \mathrm{~Hz}$, $4 \mathrm{H}, \mathrm{CH}_{2}-\mathrm{C}=\mathrm{O}$ ), 2.52-2.48 (m, $4 \mathrm{H}, \mathrm{CH}_{2}$ allylic), 2.08 (quint, $J=$ $7.5 \mathrm{~Hz}, 4 \mathrm{H}, \mathrm{CH}_{2}$ allylic), 0.98 (t, $\left.J=7.5 \mathrm{~Hz}, 6 \mathrm{H}, \mathrm{CH}_{3}\right) \mathrm{ppm} .{ }^{13} \mathrm{C}$ NMR $\left(125 \mathrm{MHz}, \mathrm{CDCl}_{3}\right): \delta=171.1,156.7,151.6,132.0,129.8$, $128.5,128.3,128.3,128.2,128.0,128.0,127.9,127.8,127.3,127.0$, 107.6, 106.7, 34.2, 25.6, 25.6, 25.6, 25.5, 22.6, 20.5, $14.2 \mathrm{ppm}$. HRMS (ESI-TOF): calcd. for $\mathrm{C}_{50} \mathrm{H}_{67} \mathrm{O}_{5}[\mathrm{M}+\mathrm{H}]^{+} 747.4989$; found 747.4994

$\left(4,4^{\prime}, 4^{\prime \prime}, 7,7^{\prime}, 7^{\prime \prime}, 10,10^{\prime}, 10^{\prime \prime}, 13,13^{\prime}, 13^{\prime \prime}, 16,16^{\prime}, 16^{\prime \prime}, 19,19^{\prime}, 19^{\prime \prime} Z\right)$ Benzene-1,3,5-triyl Tridocosa-4,7,10,13,16,19-hexaenoate (8): Coupling of di-DHA-phloroglucinol 7 (108 mg, $0.14 \mathrm{mmol})$ and DHA (46 mg, $0.15 \mathrm{mmol}$ ) was carried out according to the general procedure to give $\mathbf{8}(108 \mathrm{mg}, 73 \%)$ as a colourless oil after purification by silica gel chromatography (hexane/EtOAc, 98:2). $R_{\mathrm{f}}$ (hexane/ EtOAc, 95:5): 0.29. ${ }^{1} \mathrm{H}$ NMR (500 MHz, $\left.\mathrm{CDCl}_{3}\right): \delta=6.82(\mathrm{~s}, 3 \mathrm{H}$, $\left.\mathrm{CH}_{\text {aro }}\right), 5.48-5.28(\mathrm{~m}, 36 \mathrm{H}, \mathrm{CH}=\mathrm{CH}), 2.87-2.79\left(\mathrm{~m}, 30 \mathrm{H}, \mathrm{CH}_{2}\right.$ bis-allylic), 2.59 (t, $\left.J=7.5 \mathrm{~Hz}, 6 \mathrm{H}, \mathrm{CH}_{2}-\mathrm{C}=\mathrm{O}\right), 2.46-2.50(\mathrm{~m}, 6$ $\mathrm{H}, \mathrm{CH}_{2}$ allylic), 2.07 (quint, $J=7.5 \mathrm{~Hz}, 6 \mathrm{H}, \mathrm{CH}_{2}$ allylic), 0.97 (t, $\left.J=7.5 \mathrm{~Hz}, 9 \mathrm{H}, \mathrm{CH}_{3}\right)$ ppm. ${ }^{13} \mathrm{C} \mathrm{NMR}\left(125 \mathrm{MHz}, \mathrm{CDCl}_{3}\right): \delta=$ $170.9,151.4,132.3,130.1,128.8,128.6,128.5,128.5,128.3,128.3$, 128.2, 128.1, 127.6, 127.3, 112.9, 34.5, 25.9, 25.9, 25.8, 22.8, 20.8, 14.5 ppm. HRMS (ESI-TOF-ASAP ${ }^{+}$): calcd. for $\mathrm{C}_{72} \mathrm{H}_{97} \mathrm{O}_{6}[\mathrm{M}+$ $\mathrm{H}]^{+}$1057.7280; found 1057.7285 .

5-Methoxybenzene-1,3-diol (9a): A freshly prepared saturated solution of dry $\mathrm{HCl}$ (gas) in $\mathrm{MeOH}(17 \mathrm{~N} ; 4 \mathrm{~mL})$ was added to a suspension of phloroglucinol $(0.40 \mathrm{~g}, 3.17 \mathrm{mmol})$ in dioxane $(1 \mathrm{~mL})$. The mixture was stirred at room temperature for $3 \mathrm{~h}$. An additional amount of the saturated $\mathrm{HCl}$ solution $(1 \mathrm{~mL})$ was added, and the mixture was kept at $70{ }^{\circ} \mathrm{C}$ for $1 \mathrm{~h}$. The solvents were evaporated under vacuum, and the residue was purified by chromatography on silica gel $\left(\mathrm{CH}_{2} \mathrm{Cl}_{2} / \mathrm{MeOH}, 98: 2\right)$ to give 9a $(0.28 \mathrm{mg}, 62 \%)$ as a white solid. Dimethylated compound $\mathbf{1 4 \mathbf { a } ^ { [ 4 3 ] }}$ was also isolated (25\%). Data for 9a: $R_{\mathrm{f}}\left(\mathrm{CH}_{2} \mathrm{Cl}_{2} / \mathrm{MeOH}, 95: 5\right): 0.47 .{ }^{1} \mathrm{H} \mathrm{NMR}$ (500 MHz, [D $\left.\mathrm{D}_{4}\right]$ methanol): $\delta=5.88\left(\mathrm{~s}, 3 \mathrm{H}, \mathrm{CH}_{\mathrm{aro}}\right), 3.69(\mathrm{~s}, 3 \mathrm{H}$, $\left.\mathrm{CH}_{3} \mathrm{O}\right) \mathrm{ppm} .{ }^{13} \mathrm{C} \mathrm{NMR}\left(125 \mathrm{MHz}, \mathrm{CDCl}_{3}\right): \delta=161.7,158.1,95.7$, 94.0, 55.2 ppm. HRMS (ESI-TOF): calcd. for $\mathrm{C}_{7} \mathrm{H}_{7} \mathrm{O}_{3}[\mathrm{M}-\mathrm{H}]^{-}$ 139.0395; found 139.0397.

5-Isopropoxybenzene-1,3-diol (9b): A freshly prepared saturated solution of dry $\mathrm{HCl}$ (gas) in $i \operatorname{PrOH}(32 \mathrm{~N} ; 4 \mathrm{~mL})$ was added to a suspension of phloroglucinol $(0.40 \mathrm{~g}, 3.17 \mathrm{mmol})$ in dioxane $(1 \mathrm{~mL})$. The mixture was stirred at room temperature for $1 \mathrm{~h}$. An additional amount of the saturated $\mathrm{HCl}$ solution $(1 \mathrm{~mL})$ was added, and the mixture was kept at $70^{\circ} \mathrm{C}$ for $7 \mathrm{~h}$. The solvents were evaporated under vacuum, and the residue was purified by chromatography on silica gel $\left(\mathrm{CH}_{2} \mathrm{Cl}_{2} / \mathrm{MeOH}, 98: 2\right)$ to give $\mathbf{9 b}$
$(0.27 \mathrm{mg}, 51 \%)$ as a white solid. Dialkylated derivative $\mathbf{1 4} \mathbf{b}^{[38]}$ was also isolated (13\%). Data for 9b: $R_{\mathrm{f}}\left(\mathrm{CH}_{2} \mathrm{Cl}_{2} / \mathrm{MeOH}, 95: 5\right): 0.4 .{ }^{1} \mathrm{H}$ $\operatorname{NMR}\left(500 \mathrm{MHz}, \mathrm{CDCl}_{3}\right): \delta=5.99\left(\mathrm{~d}, J=1.9 \mathrm{~Hz}, 2 \mathrm{H}, \mathrm{CH}_{\mathrm{aro}}\right)$, $5.96\left(\mathrm{t}, J=1.9 \mathrm{~Hz}, 1 \mathrm{H}, \mathrm{CH}_{\text {aro }}\right.$ ), 5.70 (br., $2 \mathrm{H}, \mathrm{OH}$ ), 4.45 (quint, $J=7.5 \mathrm{~Hz}, 1 \mathrm{H}, \mathrm{CH}), 1.31\left(\mathrm{~d}, J=6.0 \mathrm{~Hz}, 6 \mathrm{H}, \mathrm{CH}_{3}\right) \mathrm{ppm} .{ }^{13} \mathrm{C}$ NMR (125 MHz, $\left.\mathrm{CDCl}_{3}\right): \delta=160.0,158.1,95.8,95.5,70.0$, $22.0 \mathrm{ppm}$. HRMS (ESI-TOF): calcd. for $\mathrm{C}_{9} \mathrm{H}_{11} \mathrm{O}_{3}[\mathrm{M}-\mathrm{H}]$ 167.0708; found 167.0710 .

5-Methoxy-1,3-bis(triisopropylsilyloxy)benzene (10a): Phloroglucinol-OMe 9a (100 mg, $0.71 \mathrm{mmol})$ was dissolved in dry $\mathrm{CH}_{2} \mathrm{Cl}_{2}$ $(6 \mathrm{~mL})$ and dry THF $(600 \mu \mathrm{L})$. Diisopropylethylamine (DIPEA; $257 \mu \mathrm{L}, 1.50 \mathrm{mmol})$ and TIPS-OTf $(403 \mu \mathrm{L}, 1.50 \mathrm{mmol})$ were added dropwise to the solution, and the reaction mixture was stirred at room temperature for $6 \mathrm{~h}$. Further DIPEA $(61.20 \mu \mathrm{L}$, $0.35 \mathrm{mmol})$ and TIPS-OTf $(95.9 \mu \mathrm{L}, 0.35 \mathrm{mmol})$ were added to drive the reaction to completion. After $6 \mathrm{~h}$, EtOAc $(15 \mathrm{~mL})$ was added to the mixture, and the organic layer was washed with water $(10 \mathrm{~mL})$ and brine $(10 \mathrm{~mL})$. The organic phase was dried $\left(\mathrm{MgSO}_{4}\right)$, and concentrated under vacuum. The residue was purified by chromatography on silica gel (hexane/EtOAc, 99:1) to give diprotected phloroglucinol-OMe 10a (311 mg, 96\%) as a colourless oil. $R_{\mathrm{f}}$ (hexane/EtOAc, 95:5): $0.80 .{ }^{1} \mathrm{H}$ NMR $\left(500 \mathrm{MHz}, \mathrm{CDCl}_{3}\right): \delta=$ 6.09-6.08 (m, 2 H, CH $\left.\mathrm{CH}_{\text {aro }}\right), 6.07-6.06\left(\mathrm{~m}, 1 \mathrm{H}, \mathrm{CH}_{\text {aro }}\right), 3.73(\mathrm{~s}, 3$ $\left.\mathrm{H}, \mathrm{CH}_{3} \mathrm{O}\right), 1.27-1.21(\mathrm{~m}, 6 \mathrm{H}, \mathrm{CH}-\mathrm{Si}), 1.10[\mathrm{~d}, J=7.0 \mathrm{~Hz}, 36 \mathrm{H}$, $\left.\left(\mathrm{CH}_{3}\right)_{2} \mathrm{C}\right] \mathrm{ppm} .{ }^{13} \mathrm{C} \mathrm{NMR}\left(125 \mathrm{MHz}, \mathrm{CDCl}_{3}\right): \delta=161.3,157.8$, 105.0, 99.7, 55.5, 18.2, 13.0 ppm. HRMS (ESI-TOF): calcd. for $\mathrm{C}_{25} \mathrm{H}_{49} \mathrm{O}_{3} \mathrm{Si}_{2}[\mathrm{M}+\mathrm{H}]^{+}$453.3214; found 453.3226.

5-Isopropoxy-1,3-bis(triisopropylsilyloxy)benzene (10b): Phloroglucinol-OiPr 9b $(231 \mathrm{mg}, 1.37 \mathrm{mmol})$ was dissolved in dry $\mathrm{CH}_{2} \mathrm{Cl}_{2}$ $(24 \mathrm{~mL})$. Diisopropylethylamine $(617 \mu \mathrm{L}, 3.60 \mathrm{mmol})$ and TIPSOTf $(969 \mu \mathrm{L}, 3.60 \mathrm{mmol})$ were added dropwise to the solution, and the reaction mixture was stirred at room temperature for $6 \mathrm{~h}$. EtOAc $(30 \mathrm{~mL})$ was added to the mixture, and the organic layer was washed with water $(15 \mathrm{~mL})$ and brine $(15 \mathrm{~mL})$. The organic phase was dried $\left(\mathrm{MgSO}_{4}\right)$ and concentrated under vacuum. The residue was purified by chromatography on silica gel (hexane/ EtOAc, 99.5:0.5) to give the diprotected phloroglucinol-O $i \operatorname{Pr}$ 10b (573 mg, 87\%) as a colourless oil. $R_{\mathrm{f}}$ (hexane/EtOAc, 95:5): 0.88. ${ }^{1} \mathrm{H}$ NMR (500 MHz, $\left.\mathrm{CDCl}_{3}\right): \delta=6.07-6.06\left(\mathrm{~m}, 2 \mathrm{H}, \mathrm{CH}_{\text {aro }}\right), 6.04$ $6.02\left(\mathrm{~m}, 1 \mathrm{H}, \mathrm{CH}_{\mathrm{aro}}\right), 4.42$ (quint, $\left.J=6.0 \mathrm{~Hz}, 1 \mathrm{H}, \mathrm{CH}_{i p}\right), 1.29$ [d, $\left.J=6.0 \mathrm{~Hz},\left(\mathrm{CH}_{3}\right)_{2} \mathrm{C}_{i p}\right], 1.26-1.19(\mathrm{~m}, 6 \mathrm{H}, \mathrm{CH}-\mathrm{Si}), 1.09$ [d, $J=$ $\left.6.0 \mathrm{~Hz}, 36 \mathrm{H},\left(\mathrm{CH}_{3}\right)_{2} \mathrm{C}_{\text {TIPS }}\right] \mathrm{ppm} .{ }^{13} \mathrm{C} \mathrm{NMR}\left(125 \mathrm{MHz}, \mathrm{CDCl}_{3}\right): \delta$ $=159.5,157.7,105.0,101.9,70.2,22.3,18.2,12.9$ ppm. HRMS (ESI-TOF): calcd. for $\mathrm{C}_{27} \mathrm{H}_{53} \mathrm{O}_{3} \mathrm{Si}_{2}[\mathrm{M}+\mathrm{H}]^{+}$481.3527; found 481.3537.

3-Methoxy-5-(triisopropylsilyloxy)phenol (11a): Diprotected phloroglucinol 10a $(92 \mathrm{mg}, 0.19 \mathrm{mmol})$ was dissolved in dry THF $(6.50 \mathrm{~mL}) . \mathrm{Et}_{3} \mathrm{~N} \cdot 3 \mathrm{HF}(33 \mu \mathrm{L}, 0.19 \mathrm{mmol})$ was added dropwise. The reaction was followed by TLC, and it was stopped so as to limit as much as possible the proportion of the fully deprotected derivative. The mixture was stirred for $7 \mathrm{~h}$ at room temperature, then EtOAc $(15 \mathrm{~mL})$ was added, and the organic layer was washed with water $(10 \mathrm{~mL})$ and brine $(10 \mathrm{~mL})$. The organic phase was dried $\left(\mathrm{MgSO}_{4}\right)$, and concentrated under vacuum. The residue was purified by chromatography on silica gel (hexane/EtOAc, 95:5 to 70:30) to give the monoprotected phloroglucinol 11a (37 mg, 61\%) as a white solid. The fully deprotected derivative was also isolated $(3.20 \mathrm{mg}$, $11 \%$ ). Data for 11a: $R_{\mathrm{f}}$ (hexane/EtOAc, 70:30): 0.6. ${ }^{1} \mathrm{H}$ NMR $\left(500 \mathrm{MHz}, \mathrm{CDCl}_{3}\right): \delta=6.05\left(\mathrm{~s}, 1 \mathrm{H}, \mathrm{CH}_{\mathrm{aro}}\right), 6.02-6.00(\mathrm{~m}, 2 \mathrm{H}$, $\mathrm{CH}_{\text {aro }}$ ), 4.86 (br. s, $\left.1 \mathrm{H}, \mathrm{OH}\right), 3.73\left(\mathrm{~s}, 3 \mathrm{H}, \mathrm{CH}_{3} \mathrm{O}\right), 1.29-1.20$ (m, $3 \mathrm{H}, \mathrm{CH}-\mathrm{Si}), 1.09$ [d, $\left.J=7.5 \mathrm{~Hz}, 18 \mathrm{H},\left(\mathrm{CH}_{3}\right)_{2} \mathrm{C}\right] \mathrm{ppm} .{ }^{13} \mathrm{C} \mathrm{NMR}$ $\left(125 \mathrm{MHz}, \mathrm{CDCl}_{3}\right): \delta=161.3,157.9,157.2,100.1,98.8,94.6,55.2$, 
17.9, $12.6 \mathrm{ppm}$. HRMS (ESI-TOF): calcd. for $\mathrm{C}_{16} \mathrm{H}_{27} \mathrm{O}_{3} \mathrm{Si}$ $[\mathrm{M}-\mathrm{H}]^{-}$295.1729; found 295.1730.

3-Isopropoxy-5-(triisopropylsilyloxy)phenol (11b): Diprotected phloroglucinol 10b (100 mg, $0.21 \mathrm{mmol})$ was dissolved in dry THF $(6 \mathrm{~mL})$, and $\mathrm{Et}_{3} \mathrm{~N} \cdot 3 \mathrm{HF}(68 \mu \mathrm{L}, 0.42 \mathrm{mmol})$ was added. The reaction was followed by TLC, and it was stopped so as to limit as much as possible the formation on the fully deprotected derivative. The mixture was stirred for $5 \mathrm{~h}$ at room temperature, then EtOAc $(15 \mathrm{~mL})$ was added, and the organic layer was washed with water $(10 \mathrm{~mL})$ and brine $(10 \mathrm{~mL})$. The organic phase was dried $\left(\mathrm{MgSO}_{4}\right)$, and concentrated under vacuum. The residue was purified by chromatography on silica gel (hexane/EtOAc, 95:5) to give monoprotected phloroglucinol 11b (42 mg, 62\%) as colourless oil. The fully deprotected derivative was also isolated (5 mg, 14\%). Data for 11b: $R_{\mathrm{f}}$ (hexane/EtOAc, 70:30): 0.7. ${ }^{1} \mathrm{H}$ NMR (500 MHz, $\mathrm{CDCl}_{3}$ ): $\delta=6.04\left(\mathrm{t}, J=2.5 \mathrm{~Hz}, 1 \mathrm{H}, \mathrm{CH}_{\mathrm{aro}}\right), 6.01(\mathrm{t}, J=2.5 \mathrm{~Hz}, 1 \mathrm{H}$, $\mathrm{CH}_{\text {aro }}$ ), 5.99 (t, $J=2.5 \mathrm{~Hz}, 1 \mathrm{H}, \mathrm{CH}_{\text {aro }}$ ), 4.87 (br., $\left.1 \mathrm{H}, \mathrm{OH}\right), 4.44$ (quint, $J=6.0 \mathrm{~Hz}, 1 \mathrm{H}, \mathrm{CH}_{i p}$ ), $1.31[\mathrm{~d}, J=6.0 \mathrm{~Hz}, 6 \mathrm{H}$, $\left(\mathrm{CH}_{3}\right)_{2} \mathrm{C}_{i p}$ ], $1.28-1.20(\mathrm{~m}, 3 \mathrm{H}, \mathrm{CH}-\mathrm{Si}), 1.10$ [d, $J=7.5 \mathrm{~Hz}, 18 \mathrm{H}$, $\left.\left(\mathrm{CH}_{3}\right)_{2} \mathrm{C}_{\text {TIPS }}\right] \mathrm{ppm} .{ }^{13} \mathrm{C} \mathrm{NMR}\left(125 \mathrm{MHz}, \mathrm{CDCl}_{3}\right): \delta=159.6,157.9$, $157.0,100.7,100.0,96.6,70.0,22.0,17.9,12.6$ ppm. HRMS (ESITOF): calcd. for $\mathrm{C}_{18} \mathrm{H}_{31} \mathrm{O}_{3} \mathrm{Si}[\mathrm{M}-\mathrm{H}]^{-}$323.2042; found 323.2045 .

$(4,7,10,13,16,19 Z)-3-M e t h o x y-5$-(triisopropylsilyloxy)phenyl Docosa-4,7,10,13,16,19-hexaenoate (12a): Coupling of protected phloroglucinol-OMe 11a (96 mg, $0.32 \mathrm{mmol}$ ) and DHA (106 mg, $0.32 \mathrm{mmol})$ following the general procedure gave 12a $(120 \mathrm{mg}$, $60 \%$ ) as a colourless oil after purification by silica gel chromatography (hexane/EtOAc, 99:1). $R_{\mathrm{f}}$ (hexane/EtOAc, 99:1): 0.28. ${ }^{1} \mathrm{H}$ $\operatorname{NMR}\left(500 \mathrm{MHz}, \mathrm{CDCl}_{3}\right): \delta=6.30\left(\mathrm{~s}, 1 \mathrm{H}, \mathrm{CH}_{\mathrm{aro}}\right), 6.25-6.23(\mathrm{~m}$, $\left.2 \mathrm{H}, \mathrm{CH}_{\text {aro }}\right), 5.48-5.28(\mathrm{~m}, 12 \mathrm{H}, \mathrm{CH}=\mathrm{CH}), 3.74\left(\mathrm{~s}, 3 \mathrm{H}, \mathrm{CH}_{3} \mathrm{O}\right)$, 2.87-2.79 (m, $10 \mathrm{H}, \mathrm{CH}_{2}$ bis-allylic), 2.60-2.57 (m, $2 \mathrm{H}, \mathrm{CH}_{2^{-}}$ $\mathrm{C}=\mathrm{O}$ ), 2.52-2.48 (m, $2 \mathrm{H}, \mathrm{CH}_{2}$ allylic), 2.07 (quint, $J=7.5 \mathrm{~Hz}, 2$ $\mathrm{H}, \mathrm{CH}_{2}$ allylic), 1.29-1.20 (m, $\left.3 \mathrm{H}, \mathrm{CH}-\mathrm{Si}\right), 1.09$ [d, $J=7.4 \mathrm{~Hz}, 18$ $\left.\mathrm{H},\left(\mathrm{CH}_{3}\right)_{2} \mathrm{C}\right], 0.97\left(\mathrm{t}, J=7.5 \mathrm{~Hz}, 3 \mathrm{H}, \mathrm{CH}_{3}\right) \mathrm{ppm} .{ }^{13} \mathrm{C} \mathrm{NMR}$ $\left(125 \mathrm{MHz}, \mathrm{CDCl}_{3}\right): \delta=171.2,160.8,157.4,152.0,132.0,129.6$, $128.5,128.3,128.2,128.2,128.1,128.1,128.0,127.8,127.5,127.0$, $106.3,103.8,100.4,55.4,34.3,25.6,25.6,25.5,22.7,20.5,17.8$, 14.2, 12.6 ppm. HRMS (ESI-TOF): calcd. for $\mathrm{C}_{38} \mathrm{H}_{59} \mathrm{O}_{4} \mathrm{Si}$ $[\mathrm{M}+\mathrm{H}]^{+}$607.4183; found 607.4185.

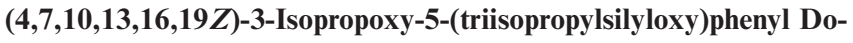
cosa-4,7,10,13,16,19-hexaenoate (12b): Coupling of mono-TIPSmono-isopropyl-phloroglucinol $\mathbf{1 1 b}(100 \mathrm{mg}, 0.31 \mathrm{mmol})$ and DHA (101 mg, $0.31 \mathrm{mmol}$ ) was carried out according to the general procedure to give 12b (132 mg, 67\%) as a colourless oil after purification by silica gel chromatography (hexane/EtOAc, 99:1). $R_{\mathrm{f}}$ (hexane/EtOAc, 99:1): 0.30. ${ }^{1} \mathrm{H}$ NMR (500 MHz, $\left.\mathrm{CDCl}_{3}\right): \delta=6.29(\mathrm{t}$, $\left.J=2.0 \mathrm{~Hz}, 1 \mathrm{H}, \mathrm{CH}_{\text {aro }}\right), 6.24\left(\mathrm{t}, J=2.0 \mathrm{~Hz}, 1 \mathrm{H}, \mathrm{CH}_{\text {aro }}\right), 6.21(\mathrm{t}, J$ $\left.=2.0 \mathrm{~Hz}, 1 \mathrm{H}, \mathrm{CH}_{\mathrm{aro}}\right), 5.49-5.29(\mathrm{~m}, 12 \mathrm{H}, \mathrm{CH}=\mathrm{CH}), 4.45$ (quint, $\left.J=6.0 \mathrm{~Hz}, 1 \mathrm{H}, \mathrm{CH}_{i p}\right), 2.88-2.81\left(\mathrm{~m}, 10 \mathrm{H}, \mathrm{CH}_{2}\right.$ bis-allylic), 2.60$2.57\left(\mathrm{~m}, 2 \mathrm{H}, \mathrm{CH}_{2}-\mathrm{C}=\mathrm{O}\right.$ ), 2.52-2.48 (m, $2 \mathrm{H}, \mathrm{CH}_{2}$ allylic), 2.08 (quint, $J=7.5 \mathrm{~Hz}, 2 \mathrm{H}, \mathrm{CH}_{2}$ allylic), $1.32[\mathrm{~d}, J=6.0 \mathrm{~Hz}, 6 \mathrm{H}$, $\left.\left(\mathrm{CH}_{3}\right)_{2} \mathrm{C}_{i p}\right], 1.28-1.22(\mathrm{~m}, 3 \mathrm{H}, \mathrm{CH}-\mathrm{Si}), 1.10[\mathrm{~d}, J=7.5 \mathrm{~Hz}, 18 \mathrm{H}$, $\left.\left(\mathrm{CH}_{3}\right)_{2} \mathrm{C}_{\text {TIPS }}\right], 0.98\left(\mathrm{t}, J=7.5 \mathrm{~Hz}, 3 \mathrm{H}, \mathrm{CH}_{3}\right) \mathrm{ppm} .{ }^{13} \mathrm{C} \mathrm{NMR}$ $\left(125 \mathrm{MHz}, \mathrm{CDCl}_{3}\right): \delta=171.1,159.1,157.3,151.9,132.0,129.6$, $128.5,128.3,128.2,128.2,128.1,128.0,128.0,127.8,127.6,127.0$, $106.0,105.3,102.3,70.1,34.3,25.6,25.6,25.5,22.7,21.9,20.5$, $17.9,14.2,12.6$ ppm. HRMS (ESI-TOF): calcd. for $\mathrm{C}_{40} \mathrm{H}_{63} \mathrm{O}_{4} \mathrm{Si}[\mathrm{M}$ $+\mathrm{H}]^{+}$635.4496; found 635.4502.

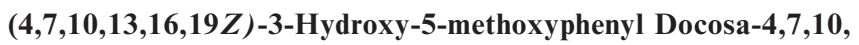
13,16,19-hexaenoate (13a): Deprotection of protected DHAphloroglucinol-OMe 12a (75 mg, $0.12 \mathrm{mmol})$ was carried out according to the general procedure to give 13a ( $49 \mathrm{mg}, 88 \%$ ) as a colourless oil after purification by silica gel chromatography (hexane/EtOAc, 90:10). $R_{\mathrm{f}}$ (hexane/EtOAc, 80:20): 0.29. ${ }^{1} \mathrm{H}$ NMR (500 MHz, $\left.\mathrm{CDCl}_{3}\right): \delta=6.25\left(\mathrm{~s}, 1 \mathrm{H}, \mathrm{CH}_{\mathrm{aro}}\right), 6.22\left(\mathrm{~s}, 1 \mathrm{H}, \mathrm{CH}_{\mathrm{aro}}\right)$, 6.18 (s, $\left.1 \mathrm{H}, \mathrm{CH}_{\text {aro }}\right), 5.49-5.28(\mathrm{~m}, 12 \mathrm{H}, \mathrm{CH}=\mathrm{CH}), 5.21$ (br., $1 \mathrm{H}$, $\mathrm{OH}), 3.75\left(\mathrm{~s}, 3 \mathrm{H}, \mathrm{CH}_{3} \mathrm{O}\right), 2.88-2.80\left(\mathrm{~m}, 10 \mathrm{H}, \mathrm{CH}_{2}\right.$ bis-allylic), $2.60\left(\mathrm{t}, J=7.3 \mathrm{~Hz}, 2 \mathrm{H}, \mathrm{CH}_{2}-\mathrm{C}=\mathrm{O}\right), 2.52-2.46\left(\mathrm{~m}, 2 \mathrm{H}, \mathrm{CH}_{2}\right.$ allylic), 2.07 (quint, $J=7.3 \mathrm{~Hz}, 2 \mathrm{H}, \mathrm{CH}_{2}$ allylic), 0.97 (t, $J=7.5 \mathrm{~Hz}$, $\left.3 \mathrm{H}, \mathrm{CH}_{3}\right)$ ppm. ${ }^{13} \mathrm{C}$ NMR $\left(125 \mathrm{MHz}, \mathrm{CDCl}_{3}\right): \delta=171.8,161.2$, $157.2,152.0,132.0,129.7,128.5,128.3,128.2,128.2,128.0,128.0$, $127.9,127.8,127.4,127.0,101.9,100.0,99.4,34.3,25.6,25.6,25.5$, 22.7, 20.5, 14.2 ppm. HRMS (ESI-TOF): calcd. for $\mathrm{C}_{29} \mathrm{H}_{39} \mathrm{O}_{4}[\mathrm{M}$ $+\mathrm{H}]^{+}$451.2848; found 451.2851 .

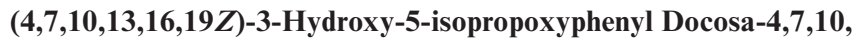
13,16,19-hexaenoate (13b): Deprotection of protected DHAphloroglucinol 12b (120 mg, $0.19 \mathrm{mmol})$ was carried out according to the general procedure to give $\mathbf{1 3 b}(82 \mathrm{mg}, 90 \%)$ as a colourless oil after purification by silica gel chromatography (hexane/EtOAc, 90:10). $R_{\mathrm{f}}$ (hexane/EtOAc, 90:10): 0.30. ${ }^{1} \mathrm{H}$ NMR $(500 \mathrm{MHz}$, $\left.\mathrm{CDCl}_{3}\right): \delta=6.25\left(\mathrm{t}, J=2.0 \mathrm{~Hz}, 1 \mathrm{H}, \mathrm{CH}_{\mathrm{aro}}\right), 6.21(\mathrm{t}, J=2.0 \mathrm{~Hz}$, $\left.1 \mathrm{H}, \mathrm{CH}_{\text {aro }}\right), 6.17\left(\mathrm{t}, J=2.0 \mathrm{~Hz}, 1 \mathrm{H}, \mathrm{CH}_{\text {aro }}\right), 5.48-5.29(\mathrm{~m}, 12 \mathrm{H}$, $\mathrm{CH}=\mathrm{CH}$ ), 4.95 (br., $1 \mathrm{H}, \mathrm{OH}$ ), 4.47 (quint, $J=6.0 \mathrm{~Hz}, 1 \mathrm{H}, \mathrm{CH}_{i p}$ ), 2.89-2.81 (m, $10 \mathrm{H}, \mathrm{CH}_{2}$ bis-allylic), 2.61-2.58 (m, $2 \mathrm{H}, \mathrm{CH}_{2}$ $\mathrm{C}=\mathrm{O}$ ), 2.54-2.48 (m, $2 \mathrm{H}, \mathrm{CH}_{2}$ allylic), 2.08 (quint, $J=7.5 \mathrm{~Hz}, 2$ $\mathrm{H}, \mathrm{CH}_{2}$ allylic), 1.32 [d, $\left.J=6.0 \mathrm{~Hz}, 6 \mathrm{H},\left(\mathrm{CH}_{3}\right)_{2} \mathrm{C}_{i p}\right], 0.98(\mathrm{t}, J=$ $\left.7.5 \mathrm{~Hz}, 3 \mathrm{H}, \mathrm{CH}_{3}\right)$ ppm. ${ }^{13} \mathrm{C} \mathrm{NMR}\left(125 \mathrm{MHz}, \mathrm{CDCl}_{3}\right): \delta=171.3$, $159.6,156.9,152.1,132.0,129.7,128.5,128.3,128.3,128.2,128.1$, $128.0,128.0,127.8,127.5,127.0,101.9,101.5,100.8,70.2,34.3$, 25.6, 25.6, 25.6, 25.5, 22.7, 21.9, 20.5, 14.2 ppm. HRMS (ESITOF): calcd. for $\mathrm{C}_{31} \mathrm{H}_{41} \mathrm{O}_{4}[\mathrm{M}-\mathrm{H}]^{-}$477.3005; found 477.3007.

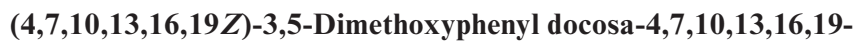
hexaenoate (15a): Coupling of commercially available di-OMephloroglucinol 14a (47 mg, $0.30 \mathrm{mmol})$ and DHA (100 mg, $0.30 \mathrm{mmol}$ ) was carried out according to the general procedure to give 15a (110 mg, 77\%) as a colourless oil after purification by silica gel chromatography (hexane/EtOAc, 97:3). $R_{\mathrm{f}}$ (hexane/ EtOAc, 95:5): 0.36. ${ }^{1} \mathrm{H}$ NMR (500 MHz, $\left.\mathrm{CDCl}_{3}\right): \delta=6.33$ (t, $J=$ $\left.2.0 \mathrm{~Hz}, 1 \mathrm{H}, \mathrm{CH}_{\text {aro }}\right), 6.25\left(\mathrm{~d}, J=2.0 \mathrm{~Hz}, 2 \mathrm{H}, \mathrm{CH}_{\text {aro }}\right), 5.49-5.28$ $(\mathrm{m}, 12 \mathrm{H}, \mathrm{CH}=\mathrm{CH}), 3.76\left(\mathrm{~s}, 6 \mathrm{H}, \mathrm{CH}_{3} \mathrm{O}\right), 2.88-2.79\left(\mathrm{~m}, 10 \mathrm{H}, \mathrm{CH}_{2}\right.$ bis-allylic), $2.60\left(\mathrm{t}, J=7.3 \mathrm{~Hz}, 2 \mathrm{H}, \mathrm{CH}_{2}-\mathrm{C}=\mathrm{O}\right), 2.54-2.49(\mathrm{~m}, 2$ $\mathrm{H}, \mathrm{CH}_{2}$ allylic), 2.07 (quint, $J=7.3 \mathrm{~Hz}, 2 \mathrm{H}, \mathrm{CH}_{2}$ allylic), 0.97 (t, $\left.J=7.5 \mathrm{~Hz}, 3 \mathrm{H}, \mathrm{CH}_{3}\right)$ ppm. ${ }^{13} \mathrm{C} \mathrm{NMR}\left(125 \mathrm{MHz}, \mathrm{CDCl}_{3}\right): \delta=$ $171.4,161.0,152.1,131.9,129.8,128.5,128.3,128.2,128.2,128.0$, $128.0,127.9,127.8,127.4,126.9,100.1,98.1,55.4,34.3,25.6,25.5$, 25.4, 22.7, 20.4, 14.2 ppm. HRMS (ESI-TOF): calcd. for $\mathrm{C}_{30} \mathrm{H}_{41} \mathrm{O}_{4}$ $[\mathrm{M}+\mathrm{H}]^{+}$465.3005; found 465.3011.

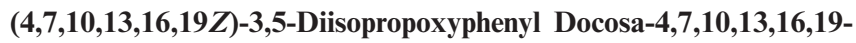
hexaenoate (15b): Coupling of di-O $i$ Pr-phloroglucinol $\mathbf{1 4 b}^{[38]}$ (96 mg, $0.45 \mathrm{mmol}$ ) and DHA (150 mg, $0.45 \mathrm{mmol}$ ) was carried out according to the general procedure to give $\mathbf{1 5 b}(168 \mathrm{mg}, 70 \%)$ as a colourless oil after purification by silica gel chromatography (hexane/EtOAc, 97:3). $R_{\mathrm{f}}$ (hexane/EtOAc, 95:5): 0.57. ${ }^{1} \mathrm{H}$ NMR $\left(500 \mathrm{MHz}, \mathrm{CDCl}_{3}\right): \delta=6.28\left(\mathrm{~s}, 1 \mathrm{H}, \mathrm{CH}_{\mathrm{aro}}\right), 6.19$ (s, $\left.2 \mathrm{H}, \mathrm{CH}_{\mathrm{aro}}\right)$, 5.48-5.28 (m, $12 \mathrm{H}, \mathrm{CH}=\mathrm{CH}), 4.46$ (quint, $J=5.9 \mathrm{~Hz}, 2 \mathrm{H}, \mathrm{CH}$ ), 2.89-2.78 (m, $10 \mathrm{H}, \mathrm{CH}_{2}$ bis-allylic), 2.59 (t, $J=7.4 \mathrm{~Hz}, 2 \mathrm{H}, \mathrm{CH}_{2}$ $\mathrm{C}=\mathrm{O}$ ), $2.53-2.48\left(\mathrm{~m}, 2 \mathrm{H}, \mathrm{CH}_{2}\right.$ allylic), 2.07 (quint, $J=7.3 \mathrm{~Hz}, 2$ $\mathrm{H}, \mathrm{CH}_{2}$ allylic), 1.31 [d, $J=6.0 \mathrm{~Hz}, 12 \mathrm{H},\left(\mathrm{CH}_{3}\right)_{2} \mathrm{C}$ ], 0.97 (t, $J=$ $\left.7.5 \mathrm{~Hz}, 3 \mathrm{H}, \mathrm{CH}_{3}\right)$ ppm. ${ }^{13} \mathrm{C} \mathrm{NMR}\left(125 \mathrm{MHz}, \mathrm{CDCl}_{3}\right): \delta=171.2$, $159.3,152.1,131.9,129.6,128.5,128.3,128.2,128.2,128.0,128.0$, $127.9,127.8,127.5,126.9,101.4,101.2,70.0,34.2,25.6,25.5,25.4$, 22.7, 21.9, 20.5, 14.2 ppm. HRMS (ESI-TOF): calcd. for $\mathrm{C}_{34} \mathrm{H}_{49} \mathrm{O}_{4}$ $[\mathrm{M}+\mathrm{H}]^{+}$521.3631; found 521.3636 .

(E)-4-(3,5-Dihydroxystyryl)phenyl Acetate (16): Resveratrol (200 mg, $0.88 \mathrm{mmol})$ was dissolved in 2-methylbutan-2-ol $(20 \mathrm{~mL})$ 
and vinyl acetate $(5 \mathrm{~mL})$ in the presence of supported Candida antarctica lipase (Novozyme 435, CALB; $1 \mathrm{~g}$ ). The mixture was stirred using a rotary evaporator at $40{ }^{\circ} \mathrm{C}$ for $4 \mathrm{~d}$. The lipase was removed by filtration, and the filter residue was washed with EtOAc $(2 \times)$ and diethyl ether. The filtrate was concentrated under reduced pressure, and the resulting residue was purified by chromatography on silica gel $\left(\mathrm{CH}_{2} \mathrm{Cl}_{2} / \mathrm{MeOH}, 99: 1\right.$ to $\left.90: 10\right)$ to give 4 '- $O$-acetyl resveratrol $16(135 \mathrm{mg}, 57 \%)$ as white solid. Starting material $(5 \mathrm{mg}$, $27 \%$ ) was also recovered after purification. Data for 16: $R_{\mathrm{f}}$ $\left(\mathrm{CH}_{2} \mathrm{Cl}_{2} / \mathrm{MeOH}, 95: 5\right): 0.30 .{ }^{1} \mathrm{H}$ NMR $\left(500 \mathrm{MHz},\left[\mathrm{D}_{4}\right]\right.$ methanol): $\delta=7.54\left(\mathrm{~d}, J=7.6 \mathrm{~Hz}, 2 \mathrm{H}, 2^{\prime}-\mathrm{H}\right.$ and $\left.6^{\prime}-\mathrm{H}\right), 7.07(\mathrm{~d}, J=7.6 \mathrm{~Hz}$, $2 \mathrm{H}, 3^{\prime}-\mathrm{H}$ and $\left.5^{\prime}-\mathrm{H}\right), 7.04(\mathrm{~d}, J=16.2 \mathrm{~Hz}, 1 \mathrm{H}, 8-\mathrm{H}), 6.97(\mathrm{~d}, J=$ $16.2 \mathrm{~Hz}, 1 \mathrm{H}, 7-\mathrm{H}), 6.49$ (s, $2 \mathrm{H}, 2-\mathrm{H}, 6-\mathrm{H}), 6.21-6.19$ (m, $1 \mathrm{H}, 4-$ $\mathrm{H}), 2.27$ [s, $\left.3 \mathrm{H}, \mathrm{CH}_{3(\mathrm{OAc})}\right]$ ppm. ${ }^{13} \mathrm{C} \mathrm{NMR}\left(125 \mathrm{MHz},\left[\mathrm{D}_{4}\right]\right.$ methanol): $\delta=171.1,159.7,151.5,140.6,136.58,130.24,128.3,128.3$, 122.9, 106.1, 103.2, 20.9 ppm. HRMS (ESI-TOF): calcd. for $\mathrm{C}_{16} \mathrm{H}_{15} \mathrm{O}_{4}[\mathrm{M}+\mathrm{H}]^{+}$271.0964; found 271.0972.

(E)-4-[3,5-Bis(triisopropylsilyloxy)styryl]phenyl Acetate (17): Resveratrol-4'-OAc 16 (100 mg, $0.37 \mathrm{mmol})$ was dissolved in dry THF $(6 \mathrm{~mL})$. Triethylamine $(109 \mu \mathrm{L}, 0.78 \mathrm{mmol})$ and TIPS-OTf ( $208 \mu \mathrm{L}, 0.78 \mathrm{mmol}$ ) were added dropwise to the solution, and the reaction mixture was stirred at room temperature for $2 \mathrm{~h}$. Further $\mathrm{Et}_{3} \mathrm{~N}(109 \mu \mathrm{L}, 0.78 \mathrm{mmol})$ and TIPS-OTf $(208 \mu \mathrm{L}, 0.78 \mathrm{mmol})$ were added to drive the reaction to completion. After a further $3 \mathrm{~h}$, the solvent was evaporated under reduced pressure. The residue was dissolved in EtOAc $(10 \mathrm{~mL})$, and this solution was washed with water $(10 \mathrm{~mL})$ and brine $(10 \mathrm{~mL})$. The organic phase was dried $\left(\mathrm{MgSO}_{4}\right)$, and concentrated under vacuum. The residue was purified by chromatography on silica gel (pentane/EtOAc, 80:20) to give protected resveratrol $17(152 \mathrm{mg}, 71 \%)$ as a colourless oil. $R_{\mathrm{f}}$ (pentane/EtOAc, 95:5): 0.5. ${ }^{1} \mathrm{H}$ NMR (500 MHz, $\mathrm{CDCl}_{3}$ ): $\delta=7.51$ $\left(\mathrm{d}, J=8.0 \mathrm{~Hz}, 2 \mathrm{H}, 2^{\prime}-\mathrm{H}\right.$ and $\left.6^{\prime}-\mathrm{H}\right), 7.09\left(\mathrm{~d}, J=8.0 \mathrm{~Hz}, 2 \mathrm{H}, 3^{\prime}-\right.$ $\mathrm{H}$ and $\left.5^{\prime}-\mathrm{H}\right), 6.98(\mathrm{~d}, J=16.3 \mathrm{~Hz}, 1 \mathrm{H}, 8-\mathrm{H}), 6.92(\mathrm{~d}, J=16.3 \mathrm{~Hz}$, $1 \mathrm{H}, 7-\mathrm{H}), 6.65$ (s, $2 \mathrm{H}, 2-\mathrm{H}, 6-\mathrm{H}), 6.37-6.36$ (m, $1 \mathrm{H}, 4-\mathrm{H}), 2.31$ $\left[\mathrm{s}, 3 \mathrm{H}, \mathrm{CH}_{3(\mathrm{OAc})}\right], 1.26(\mathrm{~m}, 6 \mathrm{H}, \mathrm{CH}-\mathrm{Si}), 1.12$ [d, $J=7.6 \mathrm{~Hz}, 36 \mathrm{H}$, $\left.\left(\mathrm{CH}_{3}\right)_{2} \mathrm{C}\right] \mathrm{ppm} .{ }^{13} \mathrm{C} \mathrm{NMR}\left(125 \mathrm{MHz}, \mathrm{CDCl}_{3}\right): \delta=169.7,157.3$, $150.2,139.0,135.3,129.3,127.8,127.7,122.0,111.6,111.5,21.4$, 18.2, 12.9 ppm. HRMS (ESI-TOF): calcd. for $\mathrm{C}_{34} \mathrm{H}_{55} \mathrm{O}_{4} \mathrm{Si}_{2}[\mathrm{M}+$ $\mathrm{H}]^{+}$583.3633; found 583.3640.

(E)-4-[3,5-Bis(triisopropylsilyloxy)styryl]phenol (18): Protected resveratrol 17 (239 $\mathrm{mg}, 0.41 \mathrm{mmol})$ was dissolved in dry $\mathrm{MeOH}$ $(2 \mathrm{~mL})$ and $\mathrm{CH}_{2} \mathrm{Cl}_{2}(1 \mathrm{~mL})$. A catalytic amount of sodium methoxide $(6.60 \mathrm{mg}, 0.12 \mathrm{mmol})$ was added to the solution, and the reaction mixture was stirred at room temperature for $2 \mathrm{~h}$. Further $\mathrm{NaOMe}$ was added to drive the reaction to completion. After $5 \mathrm{~h}$, the solvent was evaporated under reduced pressure. The residue was purified by chromatography on silica gel (hexane/EtOAc, 95:5) to give 4 '-deprotected resveratrol $18(214 \mathrm{mg}, 97 \%)$ as a colourless oil. $R_{\mathrm{f}}$ (hexane/EtOAc, 90:10): $0.41 .{ }^{1} \mathrm{H}$ NMR $(500 \mathrm{MHz}$, [D $\left.\mathrm{D}_{4}\right]$ methanol): $\delta=7.38\left(\mathrm{~d}, J=8.5 \mathrm{~Hz}, 2 \mathrm{H}, 2^{\prime}-\mathrm{H}\right.$ and $\left.6^{\prime}-\mathrm{H}\right), 6.95$ (d, $J=16.2 \mathrm{~Hz}, 1 \mathrm{H}, 8-\mathrm{H}), 6.84(\mathrm{~d}, J=16.2 \mathrm{~Hz}, 1 \mathrm{H}, 7-\mathrm{H}), 6.77$ (d, $J=8.5 \mathrm{~Hz}, 2 \mathrm{H}, 3^{\prime}-\mathrm{H}$ and $\left.5^{\prime}-\mathrm{H}\right), 6.64-6.63(\mathrm{~m}, 2 \mathrm{H}, 2-\mathrm{H}, 6-\mathrm{H})$, 6.30-6.29 (m, $1 \mathrm{H}, 4-\mathrm{H}), 1.30-1.22$ (m, $6 \mathrm{H}, \mathrm{CH}-\mathrm{Si}), 1.14$ [d, $J=$ $\left.7.5 \mathrm{~Hz}, 36 \mathrm{H},\left(\mathrm{CH}_{3}\right)_{2} \mathrm{C}\right] \mathrm{ppm} .{ }^{13} \mathrm{C} \mathrm{NMR}\left(125 \mathrm{MHz},\left[\mathrm{D}_{4}\right]\right.$ methanol): $\delta=158.5,158.3,141.3,130.1,129.9,129.0,126.5,116.5,112.1$, 111.4, 18.4, 13.9 ppm. HRMS (ESI-TOF): calcd. for $\mathrm{C}_{32} \mathrm{H}_{53} \mathrm{O}_{3} \mathrm{Si}_{2}$ $[\mathrm{M}+\mathrm{H}]^{+}$541.3527; found 541.3536

$(4,7,10,13,16,19 Z)-4-[(E)-3,5-B i s(t r i i s o p r o p y l s i l y l o x y) s t y r y l] p h e n y l$ Docosa-4,7,10,13,16,19-hexaenoate (19): Coupling of diprotected resveratrol 18 (103 mg, $0.18 \mathrm{mmol})$ and DHA (67 mg, $0.20 \mathrm{mmol})$ was carried out according to the general procedure to give $\mathbf{1 9}$ $(130 \mathrm{mg}, 80 \%)$ as a colourless oil after purification by silica gel chromatography (hexane/EtOAc, 99:1). $R_{\mathrm{f}}$ (hexane/EtOAc, 95:5): 0.73. ${ }^{1} \mathrm{H}$ NMR $\left(500 \mathrm{MHz}, \mathrm{CDCl}_{3}\right): \delta=7.50(\mathrm{~d}, J=8.5 \mathrm{~Hz}, 2 \mathrm{H}$, $2^{\prime}-\mathrm{H}$ and $\left.6^{\prime}-\mathrm{H}\right), 7.07$ (d, $J=8.4 \mathrm{~Hz}, 2 \mathrm{H}, 3^{\prime}-\mathrm{H}$ and $\left.5^{\prime}-\mathrm{H}\right), 6.98(\mathrm{~d}$, $J=16.5 \mathrm{~Hz}, 1 \mathrm{H}, 8-\mathrm{H}), 6.92(\mathrm{~d}, J=16.5 \mathrm{~Hz}, 1 \mathrm{H}, 7-\mathrm{H}), 6.64(\mathrm{~d}, J$ $=2.3 \mathrm{~Hz}, 2 \mathrm{H}, 2-\mathrm{H}, 6-\mathrm{H}), 6.36(\mathrm{t}, J=2.3 \mathrm{~Hz}, 1 \mathrm{H}, 4-\mathrm{H}), 5.50-5.29$ (m, $12 \mathrm{H}, \mathrm{CH}=\mathrm{CH}), 2.90-2.80\left(\mathrm{~m}, 10 \mathrm{H}, \mathrm{CH}_{2}\right.$ bis-allylic), $2.64(\mathrm{t}$, $J=7.0 \mathrm{~Hz}, 2 \mathrm{H}, \mathrm{CH}_{2}-\mathrm{C}=\mathrm{O}$ ), 2.55-2.51 (m, $2 \mathrm{H}, \mathrm{CH}_{2}$ allylic), 2.08 (quint, $J=7.0 \mathrm{~Hz}, 2 \mathrm{H}, \mathrm{CH}_{2}$ allylic), $1.29-1.22(\mathrm{~m}, 6 \mathrm{H}, \mathrm{CH}-\mathrm{Si})$, $1.12\left[\mathrm{~d}, J=7.5 \mathrm{~Hz}, 36 \mathrm{H},\left(\mathrm{CH}_{3}\right)_{2} \mathrm{C}\right], 0.98\left(\mathrm{t}, J=7.5 \mathrm{~Hz}, 3 \mathrm{H}, \mathrm{CH}_{3}\right)$ ppm. ${ }^{13} \mathrm{C}$ NMR $\left(125 \mathrm{MHz}, \mathrm{CDCl}_{3}\right): \delta=171.8,157.4,150.4,139.1$, $135.3,132.3,130.0,129.3,128.9,128.7,128.6,128.6,128.4,128.4$, $128.3,128.2,127.9,127.8,127.7,127.3,122.0,111.7,111.6,34.6$, $25.9,25.9,25.8,23.1,20.9,18.2,14.6,13.0$ ppm. HRMS (ESITOF): calcd. for $\mathrm{C}_{54} \mathrm{H}_{83} \mathrm{O}_{4} \mathrm{Si}_{2}[\mathrm{M}+\mathrm{H}]^{+}$851.5824; found 851.5825.

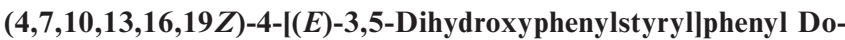
cosa-4,7,10,13,16,19-hexaenoate (20): Deprotection of protected DHA-resveratrol 19 (142 mg, $0.17 \mathrm{mmol})$ was carried out according to the general procedure to give $20(55 \mathrm{mg}, 61 \%)$ as a white solid after reaction for $7 \mathrm{~h}$ and purification by silica gel chromatography (hexane/EtOAc, 95:5 to 70:30). $R_{\mathrm{f}}$ (hexane/EtOAc, 70:30): 0.22. ${ }^{1} \mathrm{H}$ NMR $\left(500 \mathrm{MHz}, \mathrm{CDCl}_{3}\right): \delta=7.45(\mathrm{~d}, J=8.6 \mathrm{~Hz}, 2 \mathrm{H}$, $2^{\prime}-\mathrm{H}$ and $\left.6^{\prime}-\mathrm{H}\right), 7.07\left(\mathrm{~d}, J=8.5 \mathrm{~Hz}, 2 \mathrm{H}, 3^{\prime}-\mathrm{H}\right.$ and $\left.5^{\prime}-\mathrm{H}\right), 6.95(\mathrm{~d}$, $J=16.2 \mathrm{~Hz}, 1 \mathrm{H}, 8-\mathrm{H}), 6.85(\mathrm{~d}, J=16.2 \mathrm{~Hz}, 1 \mathrm{H}, 7-\mathrm{H}), 6.51(\mathrm{~d}, J$ $=2.1 \mathrm{~Hz}, 2 \mathrm{H}, 2-\mathrm{H}, 6-\mathrm{H}), 6.26(\mathrm{t}, J=2.1 \mathrm{~Hz}, 1 \mathrm{H}, 4-\mathrm{H}), 5.52-5.29$ (m, $12 \mathrm{H}, \mathrm{CH}_{2}$ bis-allylic), 5.13 (br., $2 \mathrm{H}, \mathrm{OH}$ ), 2.90-2.80 (m, 10 $\mathrm{H}, \mathrm{CH}_{2}$ allylic), $2.66\left(\mathrm{t}, J=7.4 \mathrm{~Hz}, 2 \mathrm{H}, \mathrm{CH}_{2}-\mathrm{C}=\mathrm{O}\right), 2.52-2.56(\mathrm{~m}$, $2 \mathrm{H}, \mathrm{CH}_{2}$ allylic), 2.08 (quint, $J=7.8 \mathrm{~Hz}, 2 \mathrm{H}, \mathrm{CH}_{2}$ allylic), 0.98 (t, $\left.J=7.3 \mathrm{~Hz}, 3 \mathrm{H}, \mathrm{CH}_{3}\right) \mathrm{ppm} .{ }^{13} \mathrm{C} \mathrm{NMR}\left(125 \mathrm{MHz}_{1} \mathrm{CDCl}_{3}\right): \delta=$ $172.3,157.3,150.4,140.0,135.2,132.4,130.1,128.9,128.7,128.6$, $128.6,128.6,128.5,128.4,128.4,128.3,128.2,127.8,127.7,127.3$, $122.1,106.4,102.7,34.6,25.9,25.8,23.1,20.9,14.6$ ppm. HRMS (ESI-TOF): calcd. for $\mathrm{C}_{36} \mathrm{H}_{43} \mathrm{O}_{4}[\mathrm{M}+\mathrm{H}]^{+}$539.3155; found 539.3160

1-Lyso-2-docosahexaenoyl-sn-glycero-3-phosphatidylcholine (21): Commercially available PC-16:0-DHA (Coger, France; $25 \mathrm{mg}$, $0.03 \mathrm{mmol})$ was dissolved in ethanol $(96 \% ; 250 \mu \mathrm{L})$ of in the presence of the supported lipozyme (immobilized, from Mucor miehei; $25 \mathrm{mg}$ ). The mixture was stirred at room temperature for $9 \mathrm{~h}$, and then an additional amount of the supported enzyme $(25 \mathrm{mg})$ was added to the mixture. After an overall reaction time of $29 \mathrm{~h}$, the supported enzyme was removed by filtration, and the filter residue was washed with absolute EtOH $(3 \times 3 \mathrm{~mL})$ and chloroform $(3 \times$ $3 \mathrm{~mL}$ ). The filtrate was concentrated under vacuum, and the resulting residue was purified on a Sep-Pak $\mathrm{SiOH}$ cartridge $\left(\mathrm{CHCl}_{3} /\right.$ $\mathrm{MeOH}, 100: 0$ to 60:40) to give $s n$-1-Lyso-PC-DHA $21(15 \mathrm{mg}$, $85 \%)$ as a colourless oil. Starting material (4 mg, 15\%) was recovered after the purification. $R_{\mathrm{f}}\left(\mathrm{CHCl}_{3} / \mathrm{MeOH} / \mathrm{H}_{2} \mathrm{O}, 65: 25: 4\right): 0.19$. ${ }^{1} \mathrm{H}$ NMR $\left(500 \mathrm{MHz}, \mathrm{CDCl}_{3}\right): \delta=5.41-5.29(\mathrm{~m}, 12 \mathrm{H}, \mathrm{CH}=\mathrm{CH})$, 4.96-4.91 (m, $1 \mathrm{H}, \mathrm{CH}-\mathrm{O}), 4.34-4.28$ (m, $\left.2 \mathrm{H}, \mathrm{CH}_{2}-\mathrm{O}\right), 4.06-4.00$ [m, $\left.\left.1 \mathrm{H}, \mathrm{CH}_{2(\mathrm{a})}-\mathrm{O}\right], 3.98-3.92\left[\mathrm{~m}, 1 \mathrm{H}, \mathrm{CH}_{2(\mathrm{~b})}\right)^{-\mathrm{O}}\right], 3.80-3.75(\mathrm{~m}, 2$ $\left.\mathrm{H}, \mathrm{CH}_{2}-\mathrm{N}\right), 3.69-3.65\left(\mathrm{~m}, 2 \mathrm{H}, \mathrm{CH}_{2}-\mathrm{O}\right), 3.32\left[\mathrm{~s}, 9 \mathrm{H},\left(\mathrm{CH}_{3}\right)_{3}-\mathrm{N}^{+}\right]$, 2.85-2.79 (m, $10 \mathrm{H}, \mathrm{CH}_{2}$ bis-allylic), 2.37-2.34 (m, $4 \mathrm{H}, \mathrm{CH}_{2}-\mathrm{C}=\mathrm{O}$ and $\mathrm{CH}_{2}$ allylic), 2.07 (quint, $J=7.5 \mathrm{~Hz}, 2 \mathrm{H}, \mathrm{CH}_{2}$ allylic), 0.97 (t, $\left.J=7.5 \mathrm{~Hz}, 3 \mathrm{H}, \mathrm{CH}_{3}\right) \mathrm{ppm} .{ }^{13} \mathrm{C} \mathrm{NMR}\left(125 \mathrm{MHz}, \mathrm{CDCl}_{3}\right): \delta=$ $172.9,132.2,129.5,128.8,128.6,128.5,128.5,128.3,128.3,128.2$, $128.1,128.1,127.2,73.7,66.4,63.3,60.0,59.6,54.5,34.3,25.8$, $25.8,25.8,25.8,25.8,22.8,20.8,14.5$ ppm. HRMS (ESI-TOF): calcd. for $\mathrm{C}_{30} \mathrm{H}_{51} \mathrm{NO}_{7} \mathrm{P}[\mathrm{M}+\mathrm{H}]^{+}$568.3403; found 568.3409. HPLC [Atlantis C18 $5 \mu \mathrm{m}(4.6 \times 250 \mathrm{~mm}), \mathrm{A}: \mathrm{MeOH} / \mathrm{H}_{2} \mathrm{O} / \mathrm{MeCN}$, 90:35:2.5, B: $\mathrm{MeOH} / \mathrm{H}_{2} \mathrm{O} / \mathrm{MeCN}, 100: 4: 2.5, t_{0^{\prime}}=100 / 0, t_{15^{\prime}}=100 /$ $0, t_{30^{\prime}}=0 / 100, t_{50^{\prime}}=0 / 100$, detection $\left.205 \mathrm{~nm}\right]: t_{\mathrm{R}}=25.80 \mathrm{~min}$.

4-[3,5-Bis(triisopropylsilyloxy)phenoxy]-4-oxobutanoic Acid (22): Diprotected phloroglucinol $2(1.30 \mathrm{~g}, 2.97 \mathrm{mmol})$ was dissolved in 
$\mathrm{CH}_{2} \mathrm{Cl}_{2}(30 \mathrm{~mL})$ in the presence of pyridine $(283 \mu \mathrm{L}, 3.56 \mathrm{mmol})$. Succinic anhydride $(358 \mathrm{mg}, 3.57 \mathrm{mmol})$ and DMAP $(36 \mathrm{mg}$, $0.29 \mathrm{mmol}$ ) were added to the solution at room temperature, and the mixture was heated at $50^{\circ} \mathrm{C}$. The mixture was stirred for $1 \mathrm{~d}$, and then additional amounts of the reagents [succinic anhydride (1 equiv.), and DMAP ( 0.1 equiv.)] were added. The reaction was stopped after $2 \mathrm{~d}$ by the addition of water $(20 \mathrm{~mL})$. The organic phase was washed with water and brine, dried $\left(\mathrm{MgSO}_{4}\right)$, and concentrated under vacuum. The residue was purified by chromatography on silica gel (hexane/EtOAc, 95:5 to 70:30) to give diprotected succinate phloroglucinol $22(670 \mathrm{mg}, 42 \%)$ as a white solid. $R_{\mathrm{f}}$ (hexane/EtOAc, 75:25): 0.24. ${ }^{1} \mathrm{H} \mathrm{NMR}\left(500 \mathrm{MHz}, \mathrm{CDCl}_{3}\right): \delta=$ $6.29\left(\mathrm{t}, J=2.1 \mathrm{~Hz}, 1 \mathrm{H}, \mathrm{CH}_{\mathrm{aro}}\right), 6.26\left(\mathrm{~d}, J=2.1 \mathrm{~Hz}, 2 \mathrm{H}, \mathrm{CH}_{\text {aro }}\right)$, 2.86-2.27 (m, $4 \mathrm{H}, \mathrm{CH}_{2 \text { succ }}$ ), 1.27-1.19 (m, $\left.6 \mathrm{H}, \mathrm{CH}-\mathrm{Si}\right), 1.09$ [d, J $\left.=7.3 \mathrm{~Hz}, 36 \mathrm{H},\left(\mathrm{CH}_{3}\right)_{2} \mathrm{C}\right] \mathrm{ppm} .{ }^{13} \mathrm{C} \mathrm{NMR}\left(125 \mathrm{MHz}, \mathrm{CDCl}_{3}\right): \delta=$ 178.0, 170.2, 157.1, 151.6, 109.4, 106.7, 29.0, 28.8, 17.8, 12.4 ppm. HRMS (ESI-TOF): calcd. for $\mathrm{C}_{24} \mathrm{H}_{45} \mathrm{O}_{3} \mathrm{Si}_{2}[\mathrm{M}-$ $\left.\mathrm{COCH}_{2} \mathrm{CH}_{2} \mathrm{COOH}\right]^{-}$437.2907; found 437.2905.

5-[3,5-Bis(triisopropylsilyloxy)phenoxy]-5-oxopentanoic Acid (23): Diprotected phloroglucinol 2 (100 mg, $0.23 \mathrm{mmol})$ was dissolved in $\mathrm{CH}_{2} \mathrm{Cl}_{2}(5 \mathrm{~mL})$ in the presence of pyridine $(27 \mu \mathrm{L}, 0.23 \mathrm{mmol})$. Glutaric anhydride ( $39 \mathrm{mg}, 0.34 \mathrm{mmol})$ and DMAP ( $3 \mathrm{mg}$, $0.02 \mathrm{mmol}$ ) were added to the solution at room temperature, and the mixture was heated at $40{ }^{\circ} \mathrm{C}$. The mixture was stirred for $1 \mathrm{~d}$, and then additional amounts of the reagents [glutaric anhydride (1.5 equiv.) and DMAP ( 0.1 equiv.)] were added. The reaction was stopped after $4 \mathrm{~d}$ by the addition of water $(10 \mathrm{~mL})$. The organic phase was washed with water and brine, dried $\left(\mathrm{MgSO}_{4}\right)$, and concentrated under vacuum. The residue was purified by chromatography on silica gel (pentane/EtOAc, 90:10) to give diprotected glutarate phloroglucinol $\mathbf{2 3}(90 \mathrm{mg}, 71 \%)$ as a colourless oil. $R_{\mathrm{f}}$ (pentane/EtOAc, 60:40): 0.50. ${ }^{1} \mathrm{H}$ NMR (500 MHz, $\left.\mathrm{CDCl}_{3}\right): \delta=6.28(\mathrm{t}$, $\left.J=2.2 \mathrm{~Hz}, 1 \mathrm{H}, \mathrm{CH}_{\mathrm{aro}}\right), 6.25\left(\mathrm{~d}, J=2.2 \mathrm{~Hz}, 2 \mathrm{H}, \mathrm{CH}_{\mathrm{aro}}\right), 2.61(\mathrm{t}$, $\left.J=7.4 \mathrm{~Hz}, 2 \mathrm{H}, \mathrm{CH}_{2 \text { glut }}\right), 2.51\left(\mathrm{t}, J=7.3 \mathrm{~Hz}, 2 \mathrm{H}, \mathrm{CH}_{2 \mathrm{glut}}\right), 2.06$ (quint, $J=7.3 \mathrm{~Hz}, 2 \mathrm{H}, \mathrm{CH}_{2 \mathrm{glut}}$ ), $1.27-1.20$ (m, $\left.6 \mathrm{H}, \mathrm{CH}-\mathrm{Si}\right), 1.08$ $\left[\mathrm{d}, J=7.3 \mathrm{~Hz}, 36 \mathrm{H},\left(\mathrm{CH}_{3}\right)_{2} \mathrm{C}\right] \mathrm{ppm} .{ }^{13} \mathrm{C} \mathrm{NMR}\left(125 \mathrm{MHz}, \mathrm{CDCl}_{3}\right)$ : $\delta=178.2,170.8,157.1,151.6,109.3,106.7,33.2,32.7,19.7,17.8$, 12.6 ppm. HRMS (ESI-TOF): calcd. for $\mathrm{C}_{29} \mathrm{H}_{51} \mathrm{O}_{6} \mathrm{Si}_{2}[\mathrm{M}-\mathrm{H}]^{-}$ 551.3224; found 551.3214.

1-\{5-[3,5-Bis(triisopropylsilyloxy)phenoxy]-5-oxopentanoyl\}-2docosahexaenoyl-sn-glycero-3-phosphatidylcholine (24): LysoPCDHA 21 (15 mg, $0.02 \mathrm{mmol})$ and diprotected glutaric phloroglucinol 23 (16 mg, $0.02 \mathrm{mmol})$ were dissolved in dry $\mathrm{CH}_{2} \mathrm{Cl}_{2}(2 \mathrm{~mL})$. DCC (6 mg, $0.03 \mathrm{mmol})$ and DMAP $(1 \mathrm{mg}, 8.30 \mu \mathrm{mol})$ were added to the solution, and the mixture was stirred at room temperature for $24 \mathrm{~h}$ under nitrogen. The solvent was evaporated under reduced pressure, and the residue was purified on a Sep-Pak SiOH cartridge $\left(\mathrm{CHCl}_{3} / \mathrm{MeOH}, 100: 0\right.$ to $\left.60: 40\right)$ to give polyphenolic-PC-DHA 24 $(19 \mathrm{mg}, 65 \%)$ as a colourless oil. Starting material $(5 \mathrm{mg}, 33 \%)$ was recovered during the purification. Data for $24: R_{\mathrm{f}}\left(\mathrm{CHCl}_{3} / \mathrm{MeOH} /\right.$ $\left.\mathrm{H}_{2} \mathrm{O}, 65: 25: 4\right): 0.40 .{ }^{1} \mathrm{H}$ NMR $\left(500 \mathrm{MHz}, \mathrm{CDCl}_{3}\right): \delta=6.28$ (t, $J=$ $\left.2.5 \mathrm{~Hz}, 1 \mathrm{H}, \mathrm{CH}_{\text {aro }}\right), 6.23\left(\mathrm{t}, J=2.5 \mathrm{~Hz}, 2 \mathrm{H}, \mathrm{CH}_{\text {aro }}\right), 5.41-5.28$ $(\mathrm{m}, 12 \mathrm{H}, \mathrm{CH}=\mathrm{CH}), 5.25-5.20(\mathrm{~m}, 1 \mathrm{H}, \mathrm{CH}-\mathrm{O}), 4.43$ [dd, $J=3.0$, $\left.J=12.0 \mathrm{~Hz}, 1 \mathrm{H}, \mathrm{CH}_{2(\mathrm{a})}-\mathrm{O}\right], 4.36-4.30\left(\mathrm{~m}, 2 \mathrm{H}, \mathrm{CH}_{2}-\mathrm{O}\right), 4.17$ [dd, $\left.J=6.5, J=12.0 \mathrm{~Hz}, 1 \mathrm{H}, \mathrm{CH}_{2(\mathrm{~b})}-\mathrm{O}\right], 4.02-3.95\left(\mathrm{~m}, 2 \mathrm{H}, \mathrm{CH}_{2}-\mathrm{O}\right)$, $3.80-3.77\left(\mathrm{~m}, 2 \mathrm{H}, \mathrm{CH}_{2}-\mathrm{N}\right), 3.35\left[\mathrm{~s}, 9 \mathrm{H},\left(\mathrm{CH}_{3}\right)_{3}-\mathrm{N}^{+}\right], 2.84-2.79(\mathrm{~m}$, $10 \mathrm{H}, \mathrm{CH}_{2}$ bis-allylic), 2.57 [t, $J=7.5 \mathrm{~Hz}, 2 \mathrm{H}, \mathrm{CH}_{2}-\mathrm{C}=\mathrm{O}_{\text {(glut })}$ ], $2.43\left[\mathrm{t}, J=7.5 \mathrm{~Hz}, 2 \mathrm{H}, \mathrm{CH}_{2}-\mathrm{C}=\mathrm{O}_{\text {(glut })}\right], 2.39-2.35\left[\mathrm{~m}, 4 \mathrm{H}, \mathrm{CH}_{2^{-}}\right.$ $\mathrm{C}=\mathrm{O}_{(\text {DHA) }}$ and $\mathrm{CH}_{2}$ allylic], 2.07 (quint, $J=7.5 \mathrm{~Hz}, 2 \mathrm{H}, \mathrm{CH}_{2}$ allylic), 2.00 [quint, $J=7.5 \mathrm{~Hz}, 2 \mathrm{H}, \mathrm{CH}_{2 \text { (glut) }}$ ] $1.24-1.18(\mathrm{~m}, 6 \mathrm{H}$, $\mathrm{CH}-\mathrm{Si}), 1.08$ [d, $\left.J=7.5 \mathrm{~Hz}, 36 \mathrm{H},\left(\mathrm{CH}_{3}\right)_{2} \mathrm{C}\right], 0.97$ (t, $J=7.5 \mathrm{~Hz}, 3$ $\left.\mathrm{H}, \mathrm{CH}_{3}\right)$ ppm. ${ }^{13} \mathrm{C} \mathrm{NMR}\left(125 \mathrm{MHz}, \mathrm{CDCl}_{3}\right): \delta=172.8,172.7$, $171.2,157.4,151.9,132.2,129.5,128.7,128.5,128.5,128.5,128.3$,
$128.3,128.2,128.1,128.0,127.2,109.5,107.0,70.8,66.8,63.4,63.3$, 59.4, 54.9, 34.3, 33.5, 33.2, 25.8, 25.8, 25.7, 22.8, 20.8, 20.1, 18.1, $14.5,12.8$ ppm. HRMS (ESI-TOF): calcd. for $\mathrm{C}_{59} \mathrm{H}_{101} \mathrm{NO}_{12} \mathrm{PSi}_{2}$ $[\mathrm{M}+\mathrm{H}]^{+}$1102.6594; found 1102.6608 .

1-[5-(3,5-Dihydroxyphenoxy)-5-oxopentanoyl]-2-docosahexaenoylsn-glycero-3-phosphatidylcholine (25): $\mathrm{Et}_{3} \mathrm{~N} \cdot 3 \mathrm{HF}(10 \mu \mathrm{L}$, $0.06 \mathrm{mmol})$ was added to a solution of $24(17 \mathrm{mg}, 0.01 \mathrm{mmol})$ in dry THF $(0.50 \mathrm{~mL})$. The mixture was stirred at room temperature for $4 \mathrm{~h}$. The solvent was evaporated under reduced pressure, and the residue was purified on a Sep-Pak $\mathrm{SiOH}$ cartridge $\left(\mathrm{CHCl}_{3} /\right.$ $\mathrm{MeOH}, 100: 0$ to $80: 20)$ to give deprotected polyphenolic-PC-DHA $25(10.20 \mathrm{mg}, 84 \%)$ as a colourless oil. $R_{\mathrm{f}}\left(\mathrm{CHCl}_{3} / \mathrm{MeOH} / \mathrm{H}_{2} \mathrm{O}\right.$, 65:25:4): 0.30. ${ }^{1} \mathrm{H}$ NMR $\left(500 \mathrm{MHz}, \mathrm{CDCl}_{3}\right): \delta=6.43(\mathrm{~s}, 1 \mathrm{H}$, $\left.\mathrm{CH}_{\text {aro }}\right), 6.10\left(\mathrm{~s}, 2 \mathrm{H}, \mathrm{CH}_{\mathrm{aro}}\right), 5.42-5.28(\mathrm{~m}, 12 \mathrm{H}, \mathrm{CH}=\mathrm{CH}), 5.18$ 5.14 (m, $1 \mathrm{H}, \mathrm{CH}-\mathrm{O}), 4.42-4.37$ [m, $\left.1 \mathrm{H}, \mathrm{CH}_{2(\mathrm{a})}-\mathrm{O}\right], 4.21-4.13$ [m, $3 \mathrm{H}, \mathrm{CH}_{2(\mathrm{~b})}-\mathrm{O}$ and $\left.\mathrm{CH}_{2}-\mathrm{O}\right], 4.04-3.98\left(\mathrm{~m}, 2 \mathrm{H}, \mathrm{CH}_{2}-\mathrm{O}\right), 3.52-3.46$ $\left(\mathrm{m}, 2 \mathrm{H}, \mathrm{CH}_{2}-\mathrm{N}\right), 3.03\left[\mathrm{~s}, 9 \mathrm{H},\left(\mathrm{CH}_{3}\right)_{3}-\mathrm{N}^{+}\right], 2.84-2.81(\mathrm{~m}, 10 \mathrm{H}$, $\mathrm{CH}_{2}$ bis-allylic), 2.56-2.51 [m, $\left.2 \mathrm{H}, \mathrm{CH}_{2}-\mathrm{C}=\mathrm{O}_{\text {(glut }}\right], 2.46-2.41[\mathrm{~m}$, $\left.2 \mathrm{H}, \mathrm{CH}_{2}-\mathrm{C}=\mathrm{O}_{\text {(glut }}\right], 2.37-2.33\left[\mathrm{~m}, 4 \mathrm{H}, \mathrm{CH}_{2}-\mathrm{C}=\mathrm{O}_{(\text {DHA })}\right.$ and $\mathrm{CH}_{2}$ allylic], 2.07 (quint, $J=7.5 \mathrm{~Hz}, 2 \mathrm{H}, \mathrm{CH}_{2}$ allylic), 2.01-1.95 [m, 2 $\left.\mathrm{H}, \mathrm{CH}_{2 \text { (glut) }}\right], 0.97$ (t, $\left.J=7.5 \mathrm{~Hz}, 3 \mathrm{H}, \mathrm{CH}_{3}\right) \mathrm{ppm} .{ }^{13} \mathrm{C} \mathrm{NMR}$ $\left(125 \mathrm{MHz}, \mathrm{CDCl}_{3}\right): \delta=172.7,172.6,172.1,159.5,152.5,132.2$, $129.5,128.8,128.5,128.5,128.5,128.3,128.3,128.3,128.1,128.0$, 127.2, 101.4, 101.2, 70.5, 66.1, 63.5, 62.3, 59.7, 54.0, 34.0, 33.1, 33.0, 25.9, 25.8, 25.8, 25.8, 22.8, 20.8, 20.4, 14.5 ppm. HRMS (ESITOF): calcd. for $\mathrm{C}_{41} \mathrm{H}_{61} \mathrm{NO}_{12} \mathrm{P}[\mathrm{M}+\mathrm{H}]^{+} 790.3931$; found 790.3940. HPLC [Atlantis C18 $5 \mu \mathrm{m}(4.6 \times 250 \mathrm{~mm}), \mathrm{A}: \mathrm{MeOH} /$ $\mathrm{H}_{2} \mathrm{O} / \mathrm{MeCN}, 90: 35: 2.5$, B: $\mathrm{MeOH} / \mathrm{H}_{2} \mathrm{O} / \mathrm{MeCN}, 100: 4: 2.5, t_{0^{\prime}}=100 /$ $0, t_{15^{\prime}}=100 / 0, t_{30^{\prime}}=0 / 100, t_{50^{\prime}}=0 / 100$, detection $\left.272 \mathrm{~nm}\right]: t_{\mathrm{R}}=$ $24.12 \mathrm{~min}$.

Drug Treatment of ARPE-19 Cells: ARPE-19 cells were obtained from ATCC, and were grown following the instructions in Dulbecco's Modified Eagle's Medium (DMEM)/Ham'F12 (GIBCO) containing Foetal Bovine Serum $(10 \% \mathrm{v} / \mathrm{v})$ and antibiotics $(1 \% \mathrm{v} / \mathrm{v})$ under an air $(95 \%) / \mathrm{CO}_{2}(5 \%)$ atmosphere at $37^{\circ} \mathrm{C}$. ARPE-19 cells were put into 96 -well plates $\left(3 \times 10^{4}\right.$ cells/well $)$ and cultured for $24 \mathrm{~h}$ to reach confluence before drug treatment. The cell cultures were treated with a serum-free medium containing drugs at different concentrations $(10-40 \mu \mathrm{M})$ for $1 \mathrm{~h}$, and then trans-retinal $(25 \mu \mathrm{M})$ was added for $4 \mathrm{~h}$, before rinsing with medium. The viability of the cells was determined in triplicate samples 16-20 h later, using an MTT colourimetric assay. After incubation for $2 \mathrm{~h}$ with MTT $(0.5 \mathrm{mg} / \mathrm{mL})$, the insoluble purple formazan produced was dissolved in DMSO. The absorbance at $570 \mathrm{~nm}$ and $655 \mathrm{~nm}$ of individual wells was measured using a microplate reader (BioRad 550). The percentage of viable cells was calculated as [(OD570 sample OD655 sample)/(OD570 control - OD655 control)] $\times 100 \%$; control cells were incubated with DMSO $(0.2 \%)$ and DMF $(0.14 \%)$.

Supporting Information (see footnote on the first page of this article): ${ }^{1} \mathrm{H}$ NMR spectrum of DHA from cod liver oil (p 2); ${ }^{1} \mathrm{H}$ NMR, ${ }^{13} \mathrm{C}$ NMR, HSQC, HMBC, and HPLC analysis of chromene A (pp 3-10); ${ }^{1} \mathrm{H}$ NMR and JMOD ${ }^{13} \mathrm{C}$ NMR spectra of compounds $\mathbf{1}$, 2, 3, 4, 5, 6, 7, 8, 9a, 9b, 10a, 10b, 11a, 11b, 12a, 12b, 13a, 13b, 15a, 15b, 16, 17, 18, 19, and 20 (pp 11-60); ${ }^{1} \mathrm{H}$ NMR, JMOD ${ }^{13} \mathrm{C}$ NMR, HMBC, HSQC, and HPLC analysis of compound 21 (pp 61-67); ${ }^{1} \mathrm{H}$ NMR, and JMOD ${ }^{13} \mathrm{C}$ NMR spectra of compounds 22, 23, and 24 (p 68-73); ${ }^{1} \mathrm{H}$ NMR, JMOD ${ }^{13} \mathrm{C}$ NMR, and HPLC analysis of 25 (pp 74-76).

\section{Acknowledgments}

The authors thank Dr Eric Spokas of Sebastian, FL, for proofreading the manuscript. The University of Montpellier and the Centre 
National de la Recherche Scientifique (CNRS) are thanked for their support.

[1] J. Z. Nowak, Pharmacol. Rep. 2013, 65, 288-304.

[2] Z. Wang, L. M. M. Keller, J. Dillon, E. R. Gaillard, Photochem. Photobiol. 2006, 82, 1251-1257.

[3] R. A. Harris, S. Amor, CNS Neurol. Disord. Drug Targets 2011, 10, 82-107.

[4] A. V. Cideciyan, T. S. Aleman, M. Swider, S. B. Schwartz, J. D. Steinberg, A. J. Bruker, A. M. Maguire, J. Bennett, E. M. Stone, S. G. Jacobson, Hum. Mol. Genet. 2004, 13, 525-534.

[5] C. K. Dorey, G. Wu, D. Ebenstein, A. Garsd, J. J. Weiter, Invest. Ophthalmol. Vis. Sci. 1989, 30, 1691-1699.

[6] J. R. Sparrow, K. Nakanishi, C. A. Parish, Invest. Ophthalmol. Vis. Sci. 2000, 41, 1981-1989.

[7] Y. Wu, E. Yanase, X. Feng, M. M. Siegel, J. R. Sparrow, Proc, Natl. Acad. Sci. USA 2010, 107, 7275-7280.

[8] N. L. Mata, J. Weng, G. H. Travis, Invest. Ophthalmol. Vis. Sci. 2000, 41, S144-S144.

[9] J. R. Sparrow, E. Gregory-Roberts, K. Yamamoto, A. Blonska, S. K. Ghosh, K. Ueda, J. Zhou, Prog. Retin. Eye Res. 2012, 31, 121-135.

[10] A. Maeda, T. Maeda, M. Golczak, S. Chou, A. Desai, C. L. Hoppel, S. Matsuyama, K. Palczewski, J. Biol. Chem. 2009, 284, 15173-15183.

[11] Y. Chen, K. Okano, T. Maeda, V. Chauhan, M. Golczak, A. Maeda, K. Palczewski, J. Biol. Chem. 2012, 287, 5059-5069.

[12] S. Quideau, D. Deffieux, C. Douat-Casassus, L. Pouységu, Angew. Chem. Int. Ed. 2011, 50, 586-621; Angew. Chem. 2011, 123, 610-646.

[13] D. Vauzour, A. Rodriguez-Mateos, G. Corona, M. J. OrunaConcha, J. P. Spencer, Nutrition 2010, 2, 1106-1131.

[14] C. Y. Lo, W. T. Hsiao, X. Y. Chen, J. Food Sci. 2011, 76, H90 96.

[15] J. Vercauteren, PCT/IB2008/054818, 2008.

[16] J. Vercauteren, PCT/IB2008/054814, 2008.

[17] K. A. Kang, K. H. Lee, S. Chae, R. Zhang, M. S. Jung, Y. M. Ham, J. S. Baik, N. H. Lee, J. W. Hyun, J. Cell. Biochem. 2006, 97, 609-620.

[18] M. M. Kim, S. K. Kim, Food Chem. Toxicol. 2010, 48, 2925 2933.

[19] Q. Zhu, Z. P. Zheng, K. W. Cheng, J. J. Wu, S. Zhang, Y. S. Tang, K. H. Sze, J. Chen, F. Chen, M. Wang, Chem. Res. Toxicol. 2009, 22, 1721-1727.

[20] H. Liu, L. Gu, J. Agric. Food Chem. 2012, 60, 1326-1334.

[21] M. Danihelová, J. Viskupičová, E. Sturdík, Acta Chim. Slov. 2012, 5, 59-69.

[22] M. Kampa, K. Theodoropoulou, F. Mavromati, V. Pelekanou, G. Notas, E. D. Lagoudaki, A. P. Nifli, C. Morel-Salmi, E. N.
Stathopoulos, J. Vercauteren, E. Castanas, J. Pharmacol. Exp. Ther. 2011, 337, 24-32.

[23] Y. Zhong, F. Shahidi, J. Agric. Food Chem. 2011, 59, 6526 6533.

[24] J. D. Altenburg, K. A. Harvey, S. McCray, Z. Xu, R. A. Siddiqui, Biochem. Biophys. Res. Commun. 2011, 411, 427-432.

[25] M. O. Bradley, C. S. Swindell, F. H. Anthony, P. A. Witman, P. Devanesan, N. L. Webb, S. D. Baker, A. C. Wolff, R. C. Donehower, J. Controlled Release 2001, 74, 233-236.

[26] K. A. Harvey, Z. Xu, P. Whitley, V. J. Davisson, R. A. Siddiqui, Bioorg. Med. Chem. 2010, 18, 1866-1874.

[27] R. J. Jones, R. E. Hawkins, M. M. Eatock, D. R. Ferry, F. A. Eskens, H. Wilke, T. R. Evans, Cancer Chemother. Pharmacol. 2008, 61, 435-441.

[28] M. Suh, A. A. Wierzbicki, E. Lien, M. T. Clandinin, Lipids 1996, 31, 61-64.

[29] M. Picq, P. Chen, M. Perez, M. Michaud, E. Véricel, M. Guichardant, M. Lagarde, Mol. Neurobiol. 2010, 42, 48-51.

[30] F. Thies, C. Pillon, P. Moliere, M. Lagarde, J. Lecerf, Am. J. Physiol. 1994, 267, R1273-1279.

[31] J. L. Guil-Guerrero, J. C. Loez-Martinez, M. A. Rincon-Cervera, P. Campra-Madrid, J. Am. Oil Chem. Soc. 2007, 84, 357361.

[32] N. Gamez-Meza, J. A. Noriega-Rodriguez, L. A. MedinaJuarez, J. Ortega-Garcia, J. Monroy-Rivera, F. J. Toro-Vazquez, H. S. Garcia, O. Angulo-Guerrero, Food Res. Int. 2003, 36, $721-727$.

[33] A. R. Medina, A. G. Gimenez, F. G. Camacho, J. A. S. Perez, E. M. Grima, A. C. Gomez, J. Am. Oil Chem. Soc. 1995, 72, $575-583$.

[34] D. Deffieux, S. Gaudrel-Grosay, A. Grelard, C. Chalumeau, S. Quideau, Tetrahedron Lett. 2009, 50, 6567-6571.

[35] R. A. Shenvi, E. J. Corey, Org. Lett. 2010, 12, 3548-3551.

[36] O. Dangles, Curr. Org. Chem. 2012, 16, 692-714.

[37] I. Thomsen, K. B. G. Torssell, Acta Chem. Scand. 1991, 45, 539-542.

[38] K. P. Jayasundera, S. J. Brodie, C. M. Taylor, Tetrahedron 2007, 63, 10077-10082

[39] G. Nicolosi, C. Spatafora, C. Tringali, J. Mol. Catal. A 2002, 16, 223-229.

[40] R. W. Teng, T. K. A. Bui, D. McManus, D. Armstrong, S. L. Mau, A. Bacic, Biocatal. Biotransform. 2005, 23, 109-116.

[41] A. Maeda, M. Golczak, Y. Chen, K. Okano, H. Kohno, S. Shiose, K. Ishikawa, W. Harte, G. Palczewska, T. Maeda, K. Palczewski, Nat. Chem. Biol. 2011, 8, 170-178.

[42] T. Georgiou, A. Neokleous, D. Nicolaou, B. Sears, PharmaNutrition 2014, 2, 8-11.

[43] A. Gallardo-Godoy, A. Fierro, T. H. McLean, M. Castillo, B. K. Cassels, M. Reyes-Parada, D. E. Nichols, J. Med. Chem. 2005, 48, 2407-2419.

Received: March 19, 2014 Published Online: June 4, 2014 